\author{
RESEARCH ARTICLE \\ 10.1029/2019JC015710 \\ Key Points: \\ - Water masses outflowing from \\ beneath Filchner Ice Shelf in the \\ Weddell Sea are identified and \\ linked to two distinct inflow sources \\ - The two inflow sources interact \\ with different ice shelf \\ characteristics, with meltwater, \\ being $\sim 0.4 \%$ of the outflowing \\ water masses \\ - The freshest outflow mixes with \\ ambient waters to ultimately sink \\ along the continental slope and \\ entrains overlying warmer waters
}

Correspondence to:

C. Akhoudas,

camille.akhoudas@locean-ipsl.upmc.fr

Citation:

Akhoudas, C., Sallée, J.-B., Reverdin, G., Aloisi, G., Benetti, M., Vignes, L., \& Gelado, M. (2020). Ice shelf basal melt and influence on dense water outflow in the Southern Weddell Sea. Journal of Geophysical Research: Oceans, 125, e2019JC015710. https://doi.org/10.1029/2019JC015710

Received 24 JUL 2019

Accepted 17 JAN 2020

Accepted article online 18 FEB 2020

(C)2020. American Geophysical Union. All Rights Reserved.

\section{Ice Shelf Basal Melt and Influence on Dense Water Outflow in the Southern Weddell Sea}

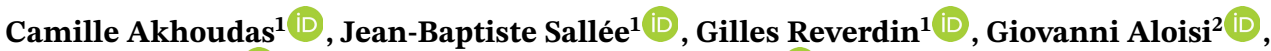 \\ Marion Benetti $^{3}$ (D), Lucie Vignes ${ }^{1}$, and Maria Gelado ${ }^{4}(\mathbb{D}$ \\ ${ }^{1}$ Sorbonne Université, CNRS/IRD/MNHN (LOCEAN UMR 7159), Paris, France, ${ }^{2}$ Institut de Physique du Globe de \\ Paris, Sorbonne Paris Cité, Univ Paris Diderot, UMR 7154 CNRS, Paris, France, ${ }^{3}$ Institute of Earth Sciences, University \\ of Iceland, Reykjavik, Iceland, ${ }^{4}$ Chemistry Department, University of Las Palmas de Gran Canaria, Las Palmas de Gran \\ Canaria, Spain
}

\begin{abstract}
We use new observations of stable water isotopes from a research cruise in early 2017 to highlight ocean-ice interactions occurring under Filchner-Ronne Ice Shelf, the largest Antarctic ice shelf. In particular, we investigate the properties of Ice Shelf Water with temperature lower than the surface freezing point, in the Filchner Depression. We identify two main flavors of Ice Shelf Water emerging from beneath the Filchner Ice Shelf, which originate from High Salinity Shelf Water end members with distinct characteristics. Furthermore, these two High Salinity Shelf Water end members interact with areas of the ice shelves with different basal properties to produce different versions of Ice Shelf Water. These water masses are associated with different rates of basal melting and refreezing, which we quantify. Ice Shelf Water types that flow out of the ice shelf cavity are composed of $0.4 \%$ of mass from ice shelf (melt minus freeze) when sampled at the front of Filchner Ice Shelf. The slightly lighter Ice Shelf Water version mixes directly with ambient water masses as it flows northward on the continental shelf. The resulting Ice Shelf Water mixture with temperature below the surface freezing point ultimately sinks along the continental slope into the deep ocean, as a precursor of the Weddell Sea bottom waters.
\end{abstract}

\section{Introduction}

The Antarctic continent is surrounded by floating ice shelves, which represent the marine termination of land ice. Buttressing by ice shelves contributes substantially to the stability of the Antarctic Ice Sheet (Dupont \& Alley, 2005), which represents the largest ice reservoir on Earth with a potential total of 58.3-m contribution to global averaged sea level rise (Vaughan et al., 2013). Over the past two decades, floating ice shelves have thinned at an increased rate compared to previous decades, which is primarily due to an increased ocean-induced basal melt (Paolo et al., 2015; Rignot et al., 2011). These changes raise pivotal questions on the future stability of the Antarctic Ice Sheet and the global sea level rise (DeConto \& Pollard, 2016; Edwards et al., 2019; Hellmer et al., 2012). Understanding the ocean circulation and ocean-ice interactions around the Antarctic continent is required to forecast future sea level rise, which might be irreversible on human time scale, with potential widespread consequences for society, particularly in coastal regions.

Ocean circulation around the Antarctic continent is, also, a key element of Earth's climate, as it fuels the global overturning circulation by producing the Antarctic Bottom Water (AABW), the world's densest water mass lying at the bottom of the ocean. This process ultimately provides ventilation and sets the characteristics of the world's ocean deep layers (DeVries \& Primeau, 2011; Foldvik et al., 1985; Orsi et al., 1999). The dense water masses that are the precursors of AABW form in some regions of the Antarctic continental shelves, notably in coastal and ice front polynyas. In polynyas where the production of sea ice is enhanced by atmospheric cooling and wind stress, very dense water (High Salinity Shelf Water, HSSW) is formed by intense brine rejection associated with sea ice production (Foldvik et al., 2001; Nicholls et al., 2009; Renfrew et al., 2002). In regions where HSSW forms, it tends to shield nearby ice shelf cavities from intrusions of relatively warm Circumpolar Deep Water and therefore reduces ice shelf basal melt (Darelius et al., 2016; Herraiz-Borreguero et al., 2015). In such regions, HSSW sinks under the ice shelf where it is transformed by ocean-ice interactions into a slightly lighter water mass called Ice Shelf Water (ISW). This type of ISW sourced by HSSW and characterized by temperatures below the surface freezing point flows out of the cavity to contribute to AABW formation. 


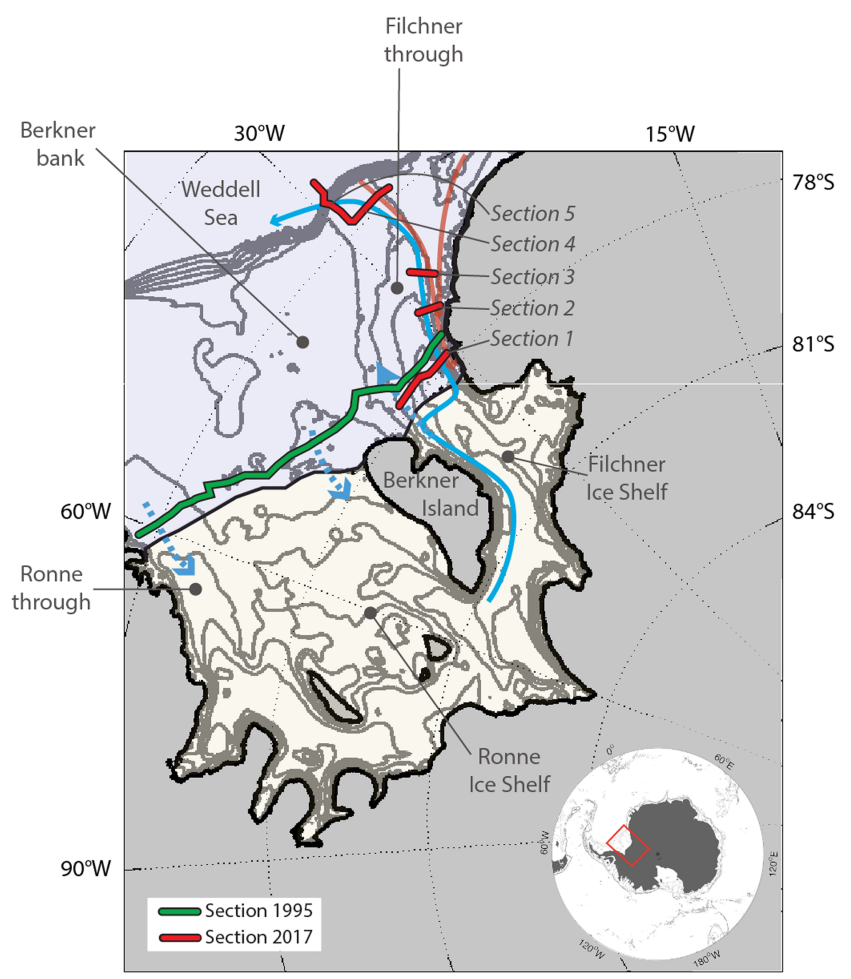

Figure 1. Map showing the position of the ship observation sections done in (red) 2017 and in (green) 1995. Schematic of the circulation in the region is superimposed on the map (Darelius et al., 2014; Nicholls et al., 2009): Dashed blue arrows correspond to possible water mass pathways between the ocean and the ice shelf cavity; blue arrows show the path of ISW, and the red arrows the southward flow of warmer mWDW. The ice shelves are shown in light yellow, the ocean in light blue, and the grounded ice in gray.
The Weddell Sea hosts the largest (by volume) Antarctic ice shelf, that is the Filchner-Ronne Ice Shelf (FRIS), and is the region producing the largest flux of AABW (Orsi et al., 1999). After accounting for recently discovered dense water formation sites around East Antarctica (Ohshima et al., 2013), it is estimated that the Weddell Sea produces about 50\% of the total AABW formed around the Antarctic continent (Meredith, 2013). In this region, HSSW forms directly in front of FRIS and enters the cavity where it interacts with the ice shelf base. This interaction adds a small fraction of glacial meltwater to a much larger volume of ambient water (Huhn et al., 2018). Freshening by meltwater creates buoyant plume that rises along the ice shelf base, either refreezing or emerging from beneath the cavity (Darelius et al., 2009; Foldvik et al., 2004). HSSW is found in different parts of the continental shelf close to FRIS, with the densest varieties commonly found in the western corner of the Ronne Ice Shelf (Ronne Trough) as well as near Berkner Bank and into the Filchner Depression (Figure 1; Darelius et al., 2014; Mackensen, 2001b; Nicholls et al., 2009). ISW escapes the cavity into the Filchner Depression (Figure 1) where it travels northward, mixing with ambient waters. Ultimately, the end product of this mixing sinks down the continental slope into the deep ocean as AABW.

The main objective of this paper is to investigate the origin and the fate of different flavors of ISW emerging from underneath Filchner Ice Shelf on the southern Weddell Sea continental shelf. In particular, we examine the rate of basal melt associated with ISW production, and the relative contribution of glacial melt that composes the cold and dense waters formed on the Weddell Sea continental shelf. To this end, we use a new set of measurements of stable water isotope composition that is a robust and conservative tracer of freshwater sources. Precipitation becomes isotopically depleted toward the South Pole and at high altitudes, which results in a very negative isotopic composition of the Antarctic Ice Sheet $(-10 \%$ o $<\delta^{18} \mathrm{O}<-60 \%$; Masson-Delmotte et al., 2008). Thus, the $\delta^{18} \mathrm{O}$ composition of Southern Ocean water masses is a valuable tracer of glacial ice mixed into the comparatively $\delta^{18} \mathrm{O}$-rich ocean $\left(\delta^{18} \mathrm{O}\right.$ of oceanic waters is typically $\sim 0 \%$; Mackensen, 2001b; Schlosser et al., 1990; Weiss et al., 1979; Weppernig et al., 1996). $\delta^{18} \mathrm{O}$ is therefore used here to explore ocean-ice interactions and the rate of mixing of glacial meltwater with ambient water masses. We use observations from an oceanographic survey carried out in January-March 2017 in the southern sector of the Weddell Sea, in front of the Filchner Ice Shelf (Figure 1). Section 2 displays the data collection and laboratory analysis and introduces the main methods of the study. Section 3 presents the results which are then discussed and summarized in section 4 .

\section{Data and Methods}

\subsection{Data Collection and Analysis}

The Wapiti expedition in the southern region of the Weddell Sea took place between 24 January and 13 March 2017 onboard the RRS James Clark Ross (Cruise JR16004). During the cruise, Conductivity-Temperature-Depth (CTD) profiles were usually collected from the sea surface to within $10 \mathrm{~m}$ of the bottom. An Oxygen Sensor SBE43 was interfaced with the CTD system and calibrated against bottle samples measured by Winkler titration. Sampling for stable water isotope analysis was performed throughout the cruise from surface to bottom with a $\sim 100$ to $200 \mathrm{~m}$ vertical resolution. All samples were drawn directly from the Niskin bottles into 30-ml glass sample vials and kept cool at $4{ }^{\circ} \mathrm{C}$ until further analysis on shore. Bottles were filled as much as possible to avoid exchange with water vapor but leaving enough air to allow for adequate mixing of the sample before measurement. The seawater samples were then analyzed at LOCEAN laboratory in Paris using a Picarro Cavity Ring-Down Spectrometer instrument (model L2130-i Isotopic $\mathrm{H}_{2} \mathrm{O}$ ) to measure for oxygen isotope composition $\left(\delta^{18} \mathrm{O}\right)$. All seawater samples were analyzed directly with the Picarro Cavity Ring-Down Spectrometer system using a stainless steel liner from Picarro that is inserted in the injection port to avoid salt accumulation in the vaporizer. The use of a liner has 
the advantage of preserving the accuracy of the seawater isotope analyses as compared to direct injections into the vaporizer. The mesh traps about $80 \%$ of the seawater salt (Benetti et al., 2017), and the precision is estimated to be at least $0.06 \%$, which is sufficient to resolve isotopic variations observed in the Weddell Sea, that is, -0.8 to $0.2 \%$ o (Brown et al., 2014; Mackensen, 2001b; Weiss et al., 1979; Weppernig et al., 1996).

The liner was replaced each day after one hundred injections. The analysis was performed by running at least six injections per sample. The first three injections were ignored to exclude potential memory effect between samples, and the remaining injections were averaged. To correct for an isotopic enrichment due to salt accumulation in the stainless steel liner, a reference freshwater was analyzed every three seawater samples. The data were then calibrated in the Vienna Standard Mean Ocean Water scale against three internal laboratory standards ( $\delta^{18} \mathrm{O}: 1.24 \%$ o, $-0.77 \%$, and $-3.26 \%$ and $\delta \mathrm{D}: 3.31 \%$, $-4.43 \%$, and $-21.32 \%$ ). These reference waters were calibrated using IAEA reference (Vienna Standard Mean Ocean Water) and stored in steel bottles with a slight overpressure of dry nitrogen to avoid exchange with ambient air. Once the data were calibrated, they were corrected for an analyzer-dependent "sea-salt effect" $\left(\delta^{18} \mathrm{O}:+0.09 \%\right.$ and $\delta \mathrm{D}$ : $+0.17 \%$; Benetti et al., 2017).

\subsection{Hydrographical Properties, Freezing, and Gade Line}

Absolute salinity (unit: $\mathrm{g} / \mathrm{kg}$, notation: $S_{A}$ ), conservative temperature (unit: ${ }^{\circ} \mathrm{C}$, notation: $\Theta$ ), and surface freezing point have been determined from practical salinity, potential temperature, and pressure using the TEOS-10 thermodynamic equation of state of seawater (Millero et al., 2008). By considering the conservation of $\Theta, S_{A}$, and the enthalpy of seawater when melting or freezing of ice occurs, the ratio of the changes in $\Theta$ over $S_{A}$ can be inferred for the limit of a small amount of ice melting into a large mass of seawater (McDougall et al., 2014). In this paper we compute this ratio based on McDougall et al. (2014), using the Matlab function "gsw_melting_ice_SA_CT_ratio" provided in the TEOS-10 package. All the details of the equation are provided in McDougall et al. (2014). We note that this relationship is entirely comparable to that of Gade (1979), although it is more general because it is based on the rigorous conservation of three basic thermodynamic properties (mass, salt, and enthalpy), so that it applies without approximation at finite amplitude and also includes the dependence of seawater enthalpy on salinity. It is also compliant with TEOS-10, which is the most recent international standard for the equation of seawater used in this paper. Similarly to the approaches described by Gade (1979) and McDougall et al. (2014), the relationship depends on the core temperature of the ice shelf $\left(\mathrm{T}_{0}\right.$ in equation (25) in Gade (1979); $\mathrm{t}^{\text {Ih }}$ in equation (16) in McDougall et al. (2014), and the water mass $\Theta, S_{A}$, and pressure at which melting or freezing occurs. In these relationships, the conductive heat flux into the ice is parameterized using the core temperature of the ice shelf, $\Theta^{i c e}$, so the slope of the changes of $\Theta$ versus $S_{A}$ is sensitive to $\Theta^{i c e}$. For simplicity and consistency with previous studies terminology, in the remainder of this paper, we will refer to the ratio of the changes in $\Theta$ over $S_{A}$ when ice melts or freezes as the "Gade line."

We computed the Gade line using $\Theta^{i c e}=-20^{\circ} \mathrm{C}$ for representing it on all figures and use a range for $\Theta^{i c e}$ of -5 to $-30^{\circ} \mathrm{C}$, which covers likely core temperatures of the ice shelf for quantifying changes in water characteristics. The range of -5 to $-30^{\circ} \mathrm{C}$ corresponds to a range of $\Theta-S_{A}$ slopes between 2.4 and $2.8^{\circ} \mathrm{C} \cdot(\mathrm{g} / \mathrm{kg})^{-1}$, classically used in previous studies using the Gade (1979) framework (e.g., Nøst \& Foldvik, 1994; Nøst \& Østerhus, 1985; Jenkins, 1999). If, during this progressive melting and cooling in the interaction with the ice shelf, the water temperature drops to the in situ freezing temperature, the melt stops. If during uplift of the water parcel (e.g., as it approaches the outflow of the ice shelf where it is much thinner), temperature falls below the local freezing temperature (freezing temperature increases as pressure decreases), it might form ice, either as frazil ice in the water column or directly deposited on the base of the ice shelf (Oerter et al., 1992). Similarly, these considerations are applied for the evolution of $\delta^{18} \mathrm{O}$ under the ocean-ice interaction (see section 2.5.2).

\subsection{Historical Data}

Ship-based observations of temperature, salinity, and pressure extracted from the World Ocean Database and PANGAEA have also been used. All profile observations located on the Weddell Sea continental shelf between $72^{\circ} \mathrm{S}$ and $80^{\circ} \mathrm{S}$ and between $24^{\circ} \mathrm{W}$ and $70^{\circ} \mathrm{W}$ that were available in these databases were considered. Only profiles that have a quality control flag of 1 or 2 were retained. In addition, we used temperature, salinity and pressure profiles derived from seal-mounted CTD tags from the MEOP database (Treasure et al., 2017).

We also used an earlier stable water isotope data set to provide a reference baseline in order to compare to our recent data. These historical data are from the cruise ANT-XII of RV Polarstern in 1995 and have been obtained from the PANGAEA database (Schröder, 2011, https://doi.pangaea.de/10.1594/PANGAEA. 756222; and Mackensen, 2001a, https://doi.pangaea.de/10.1594/PANGAEA.55750). 


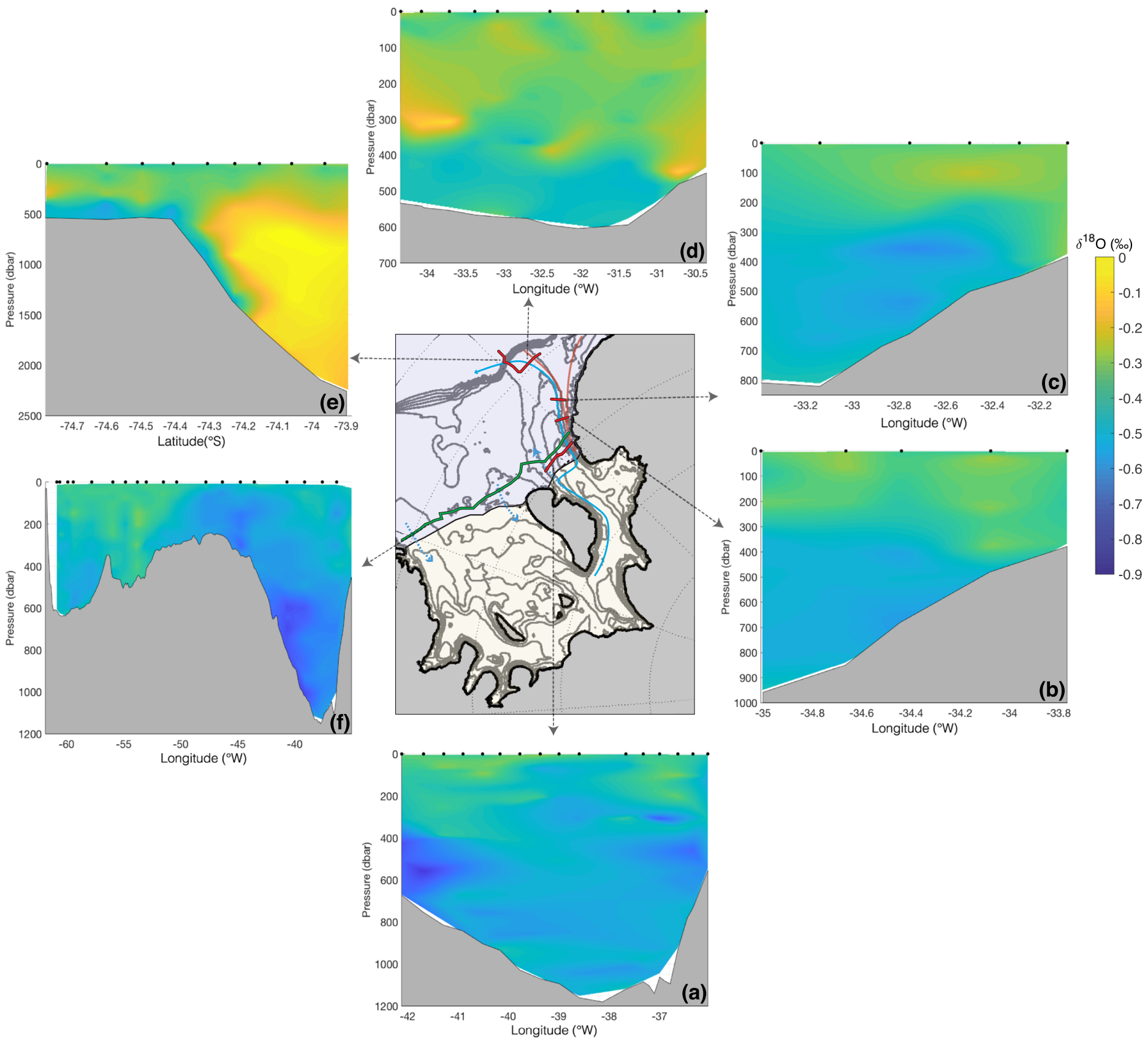

Figure 2. Vertical hydrographic sections of $\delta^{18} \mathrm{O}(\%)$ sampled in 1995 and 2017: (a) 2017 section along Filchner Ice Shelf, (b and c) 2017 meridional sections on the eastern flank of the Filchner Depression, and (d and e) 2017 sections at the continental sill and slope of the Filchner Depression; (f) 1995 section along FRIS.

\subsection{Water Masses in the Filchner Depression}

A total of 296 water isotope samples was analyzed along five sections in the Filchner Depression. The locations of the sections were chosen to document water masses on the two main southward and northward meridional pathways between the continental shelf break and the front of Filchner Ice Shelf that lie on the eastern flank of the Filchner Depression (Figure 2). From south to north, hydrographic section 1 is located along the front of Filchner Ice Shelf (Figure 2a); hydrographic sections 2 and 3 are zonal sections on the eastern part of the Filchner Depression at about $77^{\circ} \mathrm{S}$ and $76.4^{\circ} \mathrm{S}$, respectively (Figures $2 \mathrm{~b}$ and $2 \mathrm{c}$ ); hydrographic section 4 is a zonal section at about $74.5^{\circ} \mathrm{S}$, directly south of the continental sill cutting the Filchner Depression from west to east (Figure 2d); and hydrographic section 5 is a meridional section along the continental slope at the eastern edge of the Filchner Depression (Figure 2e). These sections show a range of water masses 

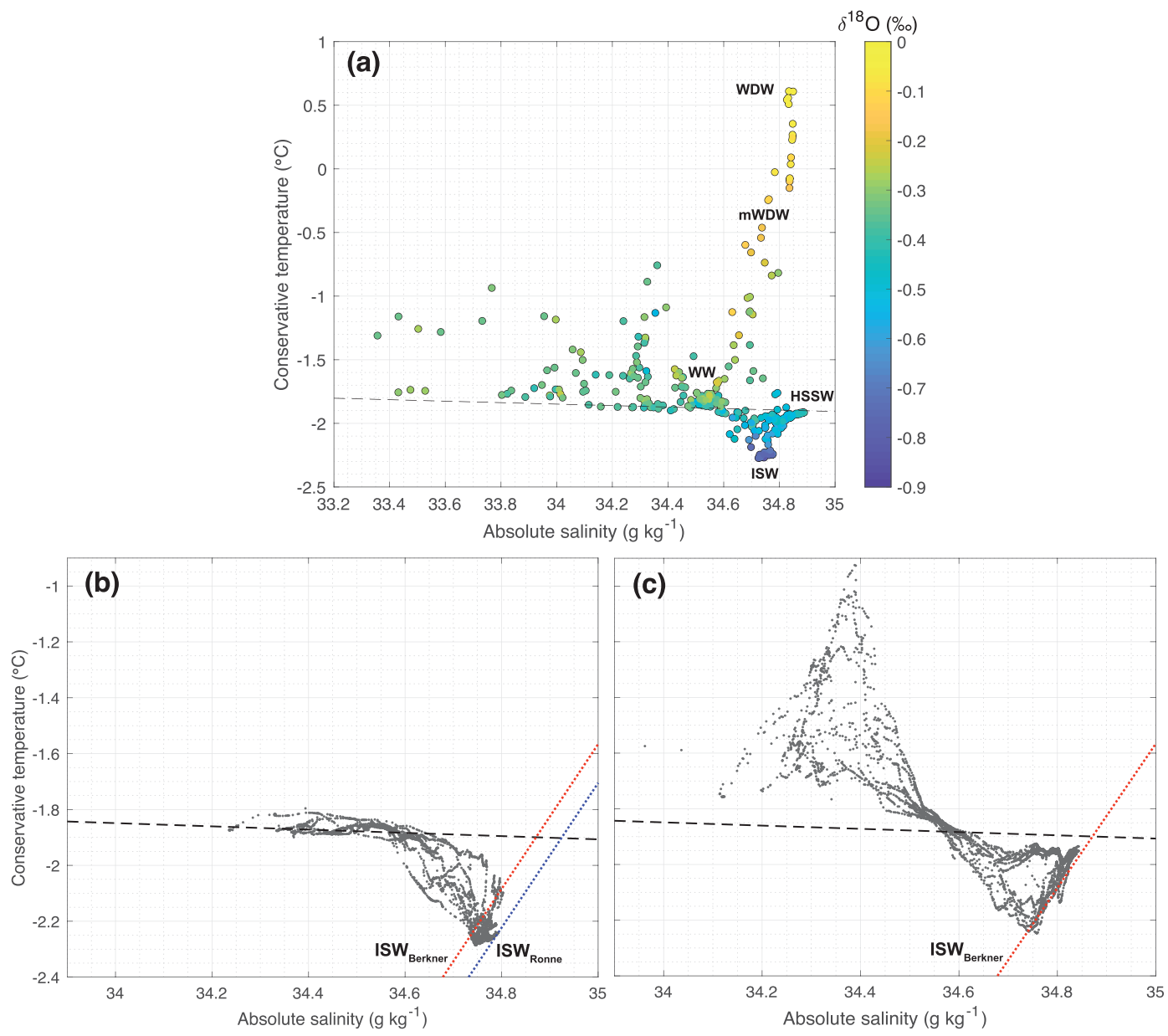

Figure 3. (a) $\Theta-S_{A}$ characteristics of all observations sampled in 2017 (observations corresponding to transects shown in Figures $2 \mathrm{a}-2 \mathrm{e}$ ), with $\delta^{18} \mathrm{O}$ values \%o shown in color. Approximate $\Theta-S_{A}$ characteristics of the main water masses of the regions are indicated: Winter Water (WW), modified Warm Deep Water (mWDW), Warm Deep Water (WDW), High Salinity Shelf Water (HSSW), and Ice Shelf Water (ISW). (b, c) $\Theta-S_{A}$ diagrams in which we extracted only the observations acquired in front of Filchner Ice Shelf in 2017 (Figure 2a) and selecting profiles sampled on the (b) western (west of $40^{\circ} \mathrm{W}$ ) and (c) eastern (east of $38^{\circ} \mathrm{W}$ ) flanks of the Filchner Depression. Red and blue dashed lines in panels (b) and (c) represent the Gade lines. In all panels, the black dashed line represents the surface freezing line.

which are typically characterized by their $\Theta-S_{A}$ properties (Figure 3a). The warmest water mass found in our domain is the Warm Deep Water (WDW), at $0.47 \pm 0.11^{\circ} \mathrm{C}$ and $34.84 \pm 0.01 \mathrm{~g} / \mathrm{kg}$ (Figure 3a and Table 1). Winter Water (WW) forms in winter through the surface cooling and brine rejection from sea ice formation and is typically found in our data set at $-1.81 \pm 0.03{ }^{\circ} \mathrm{C}$ and $34.54 \pm 0.03 \mathrm{~g} / \mathrm{kg}$ (Figure $3 \mathrm{a}$ and Table 1). As WDW and WW mix, the resulting mixture is called modified Warm Deep Water (mWDW; Foster \& Carmack, 1976). The saltiest version of the water mass at the surface freezing point, which is formed by winter brine rejection associated with sea ice formation, is referred to as HSSW. Finally, the coldest water mass of our domain, which flows from under the ice shelf, is referred to as ISW.

\subsection{Ice Shelf Properties}

In order to investigate how ocean-ice interactions affect $\delta^{18} \mathrm{O}$ and dissolved oxygen (DO) characteristics of ocean water masses, one needs to determine the $\delta^{18} \mathrm{O}$ and DO concentration of the ice shelf base that interacts with the ocean. The tools we use for that are both an observation-based range of $\delta^{18} \mathrm{O}$ and DO of Antarctic ice, which we refer to as "glaciological constraint," and the observed change in ocean properties from upstream to downstream of the ice shelf cavity, which we refer to as "oceanographic constraint."

\subsubsection{Glaciological Constraint for Ice Shelf Properties}

There are only very limited and sparse $\delta^{18} \mathrm{O}$ and DO observations of basal ice (e.g., Jenkins \& Doake, 1991; Oerter et al., 1992). Therefore, instead of using such incomplete sets of observations, we will attempt to 


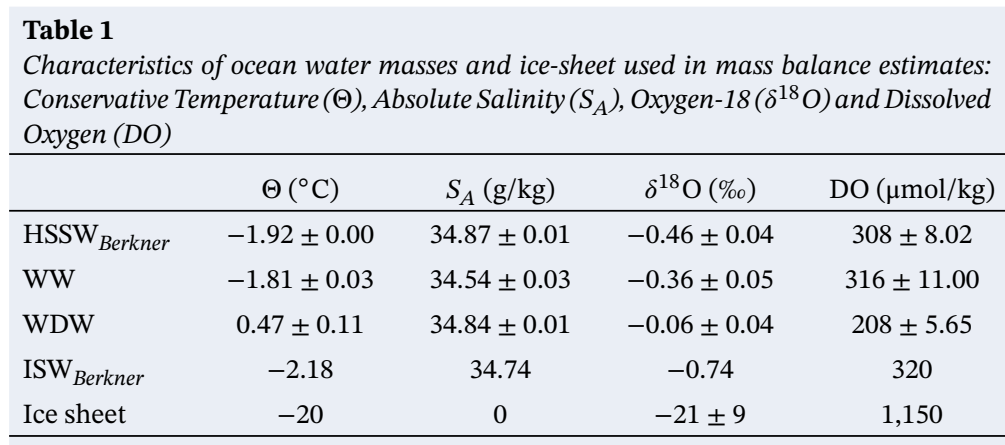

Note. Mean characteristics and associated errors of $\mathrm{HSSW}_{\text {Berkner }}$, WW, and WDW are inferred from our set of 2017 observations. Characteristics of ISW $_{\text {Berkner }}$ are estimated by solving a mass balance system of equation (equation (11)). Ice sheet conservative temperature and absolute salinity are chosen based on previous work (Mellor, 1960; Robin, 1955), and ice sheet $\delta^{18} \mathrm{O}$ and DO is estimated in section 3.2 (see Figure 5).

constrain a range of possible values for $\delta^{18} \mathrm{O}$ composition and DO concentration of the ice shelf base. $\delta^{18} \mathrm{O}$ and DO are related to the elevation where ice originally formed by snow compaction (Martinerie et al., 1992; Masson-Delmotte et al., 2008). Alternatively, ice can form by freezing of seawater with a very distinct $\delta^{18} \mathrm{O}$ and DO composition (Oerter et al., 1992), but we are for now only interested into the $\delta^{18} \mathrm{O}$ and DO composition of ice formed by snow compaction, which we will refer to in this paper as meteoric ice.

FRIS exhibits varying ice thickness ranging between $\sim 200$ and $\sim 1,500 \mathrm{~m}$ (Lambrecht et al., 2007). It is fed by ice streams at various elevations (Bentley \& Anderson, 1998; Lambrecht et al., 2007; Rippin et al., 2004; Slater et al., 2018) and by local solid precipitation on top of the ice shelf. As a result, it is difficult to precisely identify the $\delta^{18} \mathrm{O}$ and DO properties of basal ice. In order to estimate a possible range of the glacial ice $\delta^{18} \mathrm{O} / \mathrm{DO}$ composition, we use a historical database of $\delta^{18} \mathrm{O}$ (referred to as $\delta^{18} \mathrm{O}^{\text {icesheet}}$ ) snow composition at the surface of the Antarctic Ice Sheet (Masson-Delmotte et al., 2008). This database is used to establish a relationship between the elevation $H$ at the site where snow was sampled and $\delta^{18} \mathrm{O}^{\text {icesheet }}$. The amount of air, and therefore DO, also depends on the elevation $H$, so by using an empirical relationship between $\mathrm{V}_{\text {air }}$ (volume of air in $\mathrm{cm}^{3} / \mathrm{g}$ of ice) and $H$, we can ultimately link $\delta^{18} \mathrm{O}^{\text {icesheet }}$ to $\mathrm{DO}^{\text {icesheet }}$. We use the relation: $\mathrm{V}_{\text {air }}=-1.7 \cdot 10^{-5} \cdot H+0.14$, provided by Martinerie et al. (1992), which they derived from observations. Acknowledging that the volume of air is composed of $21 \%$ of oxygen, and based on the molar volume of a gas at standard temperature and pressure ( $273 \mathrm{~K}$ and $1 \mathrm{~atm}$, respectively), we convert the latter relation into a linear relationship of DO in ice $\left(\mathrm{DO}^{\text {icesheet }}\right)$ as a function of $H$ : $\mathrm{DO}^{\text {icesheet }}=-0.16 \cdot H+1,295$, which we then use to transform the observed $\delta^{18} \mathrm{O}^{\text {icesheet }}$ as a function of $\mathrm{H}$, into $\delta^{18} \mathrm{O}^{\text {icesheet }}$ as a function of $\mathrm{DO}^{\text {icesheet }}$. We note that while using basal ice observations would be more satisfying than estimating it from surface observation, the sparsity of direct observations of basal ice does not allow to document the spatial variability of ice composition at the base of the ice shelf.

\subsubsection{Oceanographic Constraint for Ice Shelf Properties}

When an ice shelf of properties ( $S^{\text {icesheet }}, \delta^{18} \mathrm{O}^{\text {icesheet }}$, and $\mathrm{DO}^{\text {icesheet }}$ ) melts into the ocean, the characteristics of the water are altered (the salinity of the ice, $S^{\text {icesheet }}$, is 0 or close to 0 , outside of basal marine ice layers. However, we derive the following equations in general terms, without assuming any given ice salinity value, keeping the variable $S^{\text {icesheet }}$ ): Water is cooled, tracers are diluted, and most dissolved gases are enriched (Jenkins, 1999). In order to evaluate the meltwater content in the resulting mixture, its characteristics must be compared with the characteristics of the source water. However, the source water might not be easy to define as it results from an arbitrary combination of different ambient waters, in the case of stratified water column (Jenkins, 1999). The problem considerably simplifies when the observed tracer content has weak vertical variability throughout the ambient water column compared to ocean-ice variability. This is the case for the water under Filchner Ice Shelf, where the incoming ambient water is not very stratified and shows weak vertical gradients compared to ocean-ice differences, at least for the tracers: salinity, $\delta^{18} \mathrm{O}$, and DO. For these tracers in the FRIS cavity, a simple linear mixing in temperature-salinity space can be assumed (Jenkins, 1999). In this paper we neglect the effect of possible subglacial runoff (Huhn et al., 2018; Jenkins, 2011), because our observations do not allow us to disentangle impact of ice melt and subglacial flow. Huhn 
et al. (2018) found evidences of freshwater from subglacial runoff only at one of the six sites sampled for noble gas investigation beneath Filchner Ice Shelf. They established that, at this site, 13\% of the total meltwater consisted of subglacial runoff versus $87 \%$ of glacial meltwater. These observations suggest that our approximation neglecting subglacial runoff will unlikely produce large errors in our analysis. However, we consider the impact of possible refreezing that will happen somewhere else along the water path under the ice shelf, either directly in contact with the ice shelf or by formation of frazil ice in the water column. Direct and satellite observations have shown the occurrence of marine ice at the base of FRIS (e.g., Bombosch \& Jenkins, 1995; Grosfeld et al., 1998; Joughin \& Padman, 2003; Lambrecht et al., 2007; Oerter et al., 1992), which is known to affect ISW characteristics (Huhn et al., 2018). Based on Jenkins (1999), we establish the following conservation equations by considering a mass budget of the water: The sum of the mass of the incoming water plus the mass added as glacial meltwater must equate the sum of the mass of the outgoing water plus the mass removed as frozen water. For conservative tracers, the conservation equation writes similarly (Jenkins, 1999):

$$
\begin{gathered}
Q_{o} \cdot S_{o}+Q_{\text {freeze }} \cdot S_{\text {freeze }}=Q_{\text {melt }} \cdot S^{\text {icesheet }}+Q_{i} \cdot S_{i}, \\
Q_{o} \cdot \delta^{18} O_{o}+Q_{\text {freeze }} \cdot \delta^{18} O_{\text {freeze }}=Q_{\text {melt }} \cdot \delta^{18} O^{\text {icesheet }}+Q_{i} \cdot \delta^{18} O_{i}, \\
Q_{o} \cdot D O_{o}+Q_{\text {freeze }} \cdot D O_{\text {freeze }}=Q_{\text {melt }} \cdot D O^{\text {icesheet }}+Q_{i} \cdot D O_{i},
\end{gathered}
$$

where the suffix "o" refers to the outgoing water, the suffix "i" refers to the ingoing water, the suffix "freeze" refers to the characteristics of the frozen water, and the suffix "melt" refers to glacial meltwater; $Q$ refers to the mass of each water constituent and is overall conserved: $Q_{o}+Q_{\text {freeze }}=Q_{\text {melt }}+Q_{i}$. The frozen water has characteristics $\left(S_{\text {freeze }}, \delta^{18} \mathrm{O}_{\text {freeze }}, \mathrm{DO}_{\text {freeze }}\right)=\left(S^{\text {icesheet }}, \delta^{18} \mathrm{O}_{i}, \mathrm{DO}_{i}\right)$, assuming here that only the salinity of the water changes as water freezes. This also assumes that DO is conserved and that there is no fractionation for $\delta^{18} \mathrm{O}$ during refreezing. Fractionation is on the order of 2\%o (Melling \& Moore, 1995; Toyota et al., 2013; Pfirman et al., 2004) but is very uncertain due to unknown proportion of frazil ice and direct ice formation on the ice shelf basal surface; nevertheless, it is much less than the typical difference between water and ice $\delta^{18} \mathrm{O}$ values (Lehmann \& Siegenthaler, 1991). These assumptions are warranted due to the small percentage of net melt and the much higher contrast between seawater and ice shelf properties than in the terms we neglect.

We can now rewrite the previous system of equations (equations (1) to (3)) and introduce the notion of "fractions" of mass, $f$, by dividing all mass quantities by the mass of the outgoing water, $Q_{o}$, so that $1+$ $f_{\text {freeze }}=f_{\text {melt }}+f_{i}$. Equations (1) to 3 can therefore be rewritten by replacing $\left(S_{\text {freeze }}, \delta^{18} \mathrm{O}_{\text {freeze }}\right.$, DO $\left.\mathrm{freeze}\right)$ by their counterpart, and using $f_{i}=1+f_{\text {freeze }}-f_{\text {melt }}$, as follows:

$$
\begin{gathered}
S_{o}+f_{\text {freeze }} \cdot S^{\text {icesheet }}=f_{\text {melt }} \cdot S^{\text {icesheet }}+\left(1+f_{\text {freeze }}-f_{\text {melt }}\right) \cdot S_{i}, \\
\delta^{18} O_{o}+f_{\text {freeze }} \cdot \delta^{18} O_{i}=f_{\text {melt }} \cdot \delta^{18} O^{\text {icesheet }}+\left(1+f_{\text {freeze }}-f_{\text {melt }}\right) \cdot \delta^{18} O_{i}, \\
D O_{o}+f_{\text {freeze }} \cdot D O_{i}=f_{\text {melt }} \cdot D O^{\text {icesheet }}+\left(1+f_{\text {freeze }}-f_{\text {melt }}\right) \cdot D O_{i} .
\end{gathered}
$$

We will also now refer to the incoming water as HSSW, and the outgoing water as ISW, and reorganize equations (4) to 6 into the following:

$$
\begin{gathered}
S^{I S W}=\left(f_{\text {melt }}-f_{\text {freeze }}\right) \cdot S^{\text {icesheet }}+\left(1+f_{\text {freeze }}-f_{\text {melt }}\right) \cdot S_{H S S W}, \\
\delta^{18} O^{I S W}=f_{\text {melt }} \cdot \delta^{18} O^{\text {icesheet }}+\left(1-f_{\text {melt }}\right) \cdot \delta^{18} O^{H S S W} \\
D O^{I S W}=f_{\text {melt }} \cdot D O^{\text {icesheet }}+\left(1-f_{\text {melt }}\right) \cdot D O^{H S S W}
\end{gathered}
$$


We then combine equations (8) and (9), to express $\delta^{18} \mathrm{O}^{\text {icesheet }}$ as a function of DO ${ }^{\text {icesheet }}$, depending on the observed ocean properties: $\delta^{18} \mathrm{O}^{I S W}, \delta^{18} \mathrm{O}^{H S S W}, \mathrm{DO}^{I S W}$, and $\mathrm{DO}^{H S S W}$ :

$$
\delta^{18} O^{i c e s h e e t}=\frac{\delta^{18} O^{H S S W}-\delta^{18} O^{I S W}}{D O^{H S S W}-D O^{I S W}} \cdot\left(D O^{i c e s h e e t}-D O^{H S S W}\right)+\delta^{18} O^{H S S W} .
$$

In other words, the observed change of $\delta^{18} \mathrm{O}$ and DO in seawater, as it flows in the cavity and is transformed from HSSW to ISW, constrains the range of possible values of $\delta^{18} \mathrm{O}^{\text {icesheet }}$ and $\mathrm{DO}^{\text {icesheet }}$ that interacted with the ocean. We will use this relationship in addition to the glaciological constraint (see section 2.5.1) to estimate the properties of the ice shelf base that interacted with the ocean. In this paper, we also compute the fraction of melt and freeze by solving a system of three equations composed of equations (7) and (8) and mass conservation (see section 3.2).

\subsection{Mass Balance Calculations}

We seek to determine the composition of ISW observed at the front of Filchner Ice Shelf, in the Filchner Depression and north of it (Figure 1) as a mixture of the different water masses on the continental shelf, namely: HSSW, ISW, WW, and WDW. We therefore solve for the following system of conservation equations:

$$
\left\{\begin{array}{l}
f_{H S S W}+f_{I S W}+f_{w w}+f_{W D W}=1 \\
f_{H S S W} \cdot S_{A}^{H S S W}+f_{I S W} \cdot S_{A}^{I S W}+f_{w w} \cdot S_{A}^{W W}+f_{W D W} \cdot S_{A}^{W D W}=S_{A}^{o b s} \\
f_{H S S W} \cdot \delta^{18} O^{H S S W}+f_{I S W} \cdot \delta^{18} O^{I S W}+f_{w w} \cdot \delta^{18} O^{W W}+f_{W D W} \cdot \delta^{18} O^{W D W}=\delta^{18} O^{o b s} \\
f_{H S S W} \cdot D O^{H S S W}+f_{I S W} \cdot D O^{I S W}+f_{w w} \cdot D O^{W W}+f_{W D W} \cdot D O^{W D W}=D O^{o b s}
\end{array}\right.
$$

where $f$ corresponds to the estimated fraction. The end member characteristics $\left(S_{A}, \delta^{18} \mathrm{O}\right.$, and DO) for the water masses HSSW, ISW, WW, and WDW are estimated and set prior to solving the system of equations. In a few instances, the system of equations produced negative fractions, which is physically inconsistent. In such cases, the fraction of the given water mass was forced to 0 and other fractions adjusted to match mass balance.

\section{Results}

\subsection{Circulation and Characteristics of HSSW and ISW}

The coldest and most $\delta^{18} \mathrm{O}$ depleted flavors of ISW emerge from beneath Filchner Ice Shelf at a depth between 400 and 600 dbar on both the eastern and western sides of the Filchner Depression (Figure 2a) where they are thought to flow northward (e.g., Darelius et al., 2014; Darelius \& Sallée, 2018; Nicholls et al., 2009). These water masses are formed as HSSW interacts with the glacier ice on its pathway in the ice shelf cavity. We now explore how ISW forms from HSSW through ocean-ice interactions. To identify the properties of HSSW implicated in the ISW formation process, we first examine the water mass characteristics of the ISW observed in front of Filchner Ice Shelf (Figure 2a). For that we zoom onto the $\Theta-S_{A}$ characteristics of ISW emerging at the western (Figure 3b) and eastern flanks (Figure 3c) of the Filchner Depression, and use the Gade lines (see section 2.2) intersecting with water mass characteristics of the ISW. Because HSSW is formed from brine rejection as sea ice forms at the surface freezing temperature, the intersection of the Gade line with the surface freezing line gives us an estimate of the source salinity, for given ISW characteristics (Nøst \& Østerhus, 1985).

On the eastern side of the Filchner Depression, the bulk of all ISW observations is aligned on one particular Gade line (Figure 3c). The intersection of the Gade line with the surface freezing line indicates a HSSW source water with an absolute salinity around $\sim 34.87 \mathrm{~g} / \mathrm{kg}$, aligning with a version of ISW with an absolute salinity of $\sim 34.74 \mathrm{~g} / \mathrm{kg}$ (Figure 3c). On the western side of the Filchner Depression (Figure 3b), the coldest part of ISW is less well defined than on the eastern side, with a spread of absolute salinity ranging from $\sim 34.74$ to $\sim 34.77 \mathrm{~g} / \mathrm{kg}$. Similar to what was done for the eastern ISW, we use the Gade lines to estimate that the western ISW is sourced from water of absolute salinity ranging from $\sim 34.87$ to $\sim 34.93 \mathrm{~g} / \mathrm{kg}$. These results suggest that there are two main HSSW sources at absolute salinity around $\sim 34.87$ and $\sim 34.93 \mathrm{~g} / \mathrm{kg}$; while the observed ISW at the eastern side of the Filchner Depression is formed only by the former, the observed ISW at the western side results from the two sources with their derived ISW being mixed together inside the cavity. One goal of this paper is to establish the amount and characteristics of the ice shelf that melts 
into HSSW to form ISW. Based on the preceding analysis, to address this goal, we consider two HSSW end members at absolute salinity of $\sim 34.87$ and $\sim 34.93 \mathrm{~g} / \mathrm{kg}$ and investigate how they transform into two ISW types at respectively absolute salinity of $\sim 34.74$ and $\sim 34.77 \mathrm{~g} / \mathrm{kg}$. The ISW observed at the western side of the Filchner Depression is a mixing product of the two resulting flavors of ISW. While here we assume that mixing occurs between them, we note that one alternative would be that the mixing occurs between the two identified HSSW end members, forming a range of HSSW that would then transform into a range of ISW as it interacts with the ice.

We now use historical observations to geographically locate where such HSSW end members could be found on the southern Weddell Sea continental shelf. A 1995 along-ice shelf section (Figures $2 \mathrm{f}$ and $4 \mathrm{a}$ ) shows that the range of absolute salinity referred to the HSSW end member types was mostly found in two regions: the Ronne Trough (west of $\left.\sim 57^{\circ} \mathrm{W}\right)$ and the Berkner Bank $\left(\sim 48^{\circ} \mathrm{W}\right)$. We also used the compiled historical CTD stations (see section 2.3) from which we focused only at the front sector of FRIS and reported where absolute salinity of $\sim 34.93$ and $\sim 34.87 \mathrm{~g} / \mathrm{kg}$ are usually found. Both salinities are found at the western Ronne Ice Front for all available historical sections (Figures $4 \mathrm{~b}$ and $4 \mathrm{c}$ ). If we now use the complete set of historical CTD stations on the Weddell Sea continental shelf between $\sim 72-80^{\circ} \mathrm{S}$ and between $\sim 24-70^{\circ} \mathrm{W}$, it is clear that most of the observations of water at $S_{A} \sim 34.93 \mathrm{~g} / \mathrm{kg}$ are found at the western side of the Ronne Trough (Figure $4 \mathrm{~d}$ ). However, water masses with salinities of $\sim 34.87 \mathrm{~g} / \mathrm{kg}$ are also regularly found near Berkner Bank and spreading in the Filchner Depression (Figure 4e; Foldvik et al., 1985; Darelius et al., 2014; Nicholls et al., 2001).

In summary, we show that the densest HSSW enters the ice shelf cavity via the western side of the Ronne Trough and the inflow of less saline version of HSSW occurs near the Berkner Bank where it reaches the cavity at the eastern side of Ronne Ice Shelf (Foldvik et al., 2001) or at the western side of Filchner Ice Shelf. Those two pathways, a salty one on the Ronne side and a less salty one on the Filchner side, circulate inside the cavity and interact with the basal ice where they are transformed in several flavors of ISW with temperatures below the surface freezing point before emerging at the front of Filchner Ice Shelf.

The historical salinity observations suggest, therefore, that the precursor of the most saline version of ISW observed at the western flank of the Filchner Depression corresponds to HSSW located in the Ronne Trough with absolute salinity around $\sim 34.93 \mathrm{~g} / \mathrm{kg}$. We propose that this water mass penetrates southward under the ice shelf at this location before emerging as ISW at the western side of the Filchner Depression. Hereafter, we refer to this HSSW end member as $\mathrm{HSSW}_{\text {Ronne. }}$. This is consistent with multiyear under-ice shelf mooring observations at the southern side of Berkner Island that report water mass characteristics consistent with HSSW $_{\text {Ronne }}$ (T. Hattermann, personal communication, September 2018; Nicholls et al., 2001). This would indicate that this HSSW end member travels around Berkner Island arriving at the western side of Filchner Ice Shelf as a flavor of ISW with an absolute salinity of about $\sim 34.77 \mathrm{~g} / \mathrm{kg}$, which is now referred as ISW Ronne $_{\text {. }}$

For the slightly lighter version of ISW observed at both front sides of Filchner Ice Shelf, the source location of HSSW end member is less clear, as two potential precursors are plausible (i.e., western Ronne Trough and Berkner Bank sources). Nevertheless, observations from multiyear moorings located under the ice shelf, at the southern side of the Berkner Island, have never reported water masses that could be associated with a source salinity around $\sim 34.87 \mathrm{~g} / \mathrm{kg}$ (T. Hattermann, personal communication, September 2018; Nicholls et al., 2001). It is, therefore, unlikely that a HSSW end member source water at $\sim 34.87 \mathrm{~g} / \mathrm{kg}$ would follow a similar path to $\mathrm{HSSW}_{\text {Ronne }}$ with an absolute salinity around $\sim 34.93 \mathrm{~g} / \mathrm{kg}$. An alternative hypothesis is that the end member source with an absolute salinity around $\sim 34.87 \mathrm{~g} / \mathrm{kg}$ is locally formed at the Berkner Bank, either traveling inside the cavity at the western side of the Berkner Island or filling the Filchner Depression, which is consistent with what has been discussed in past studies (e.g., Carmack \& Foster, 1975; Darelius et al., 2014; Gammelsrød et al., 1994; Huhn et al., 2018). This HSSW end member is now referred to as $\mathrm{HSSW}_{\text {Berkner }}$ which defines the production of the slightly lighter flavor of ISW, that is, $\mathrm{ISW}_{\text {Berkner }}$.

Using the full-depth distribution of $\delta^{18} \mathrm{O}$ from the Filchner Depression (sections 1-5) where $\mathrm{HSSW}_{\text {Berkner }}$ was sampled, we determine its isotopic composition to be $-0.46 \pm 0.04 \%$. Using $\delta^{18} \mathrm{O}$ observations from Mackensen (2001a) that sampled the Ronne Trough, we determine the isotopic composition of HSSW $_{\text {Ronne }}$ as $-0.52 \pm 0.01 \%$. Now that the characteristics of the two flavors of ISW and of their HSSW end member 

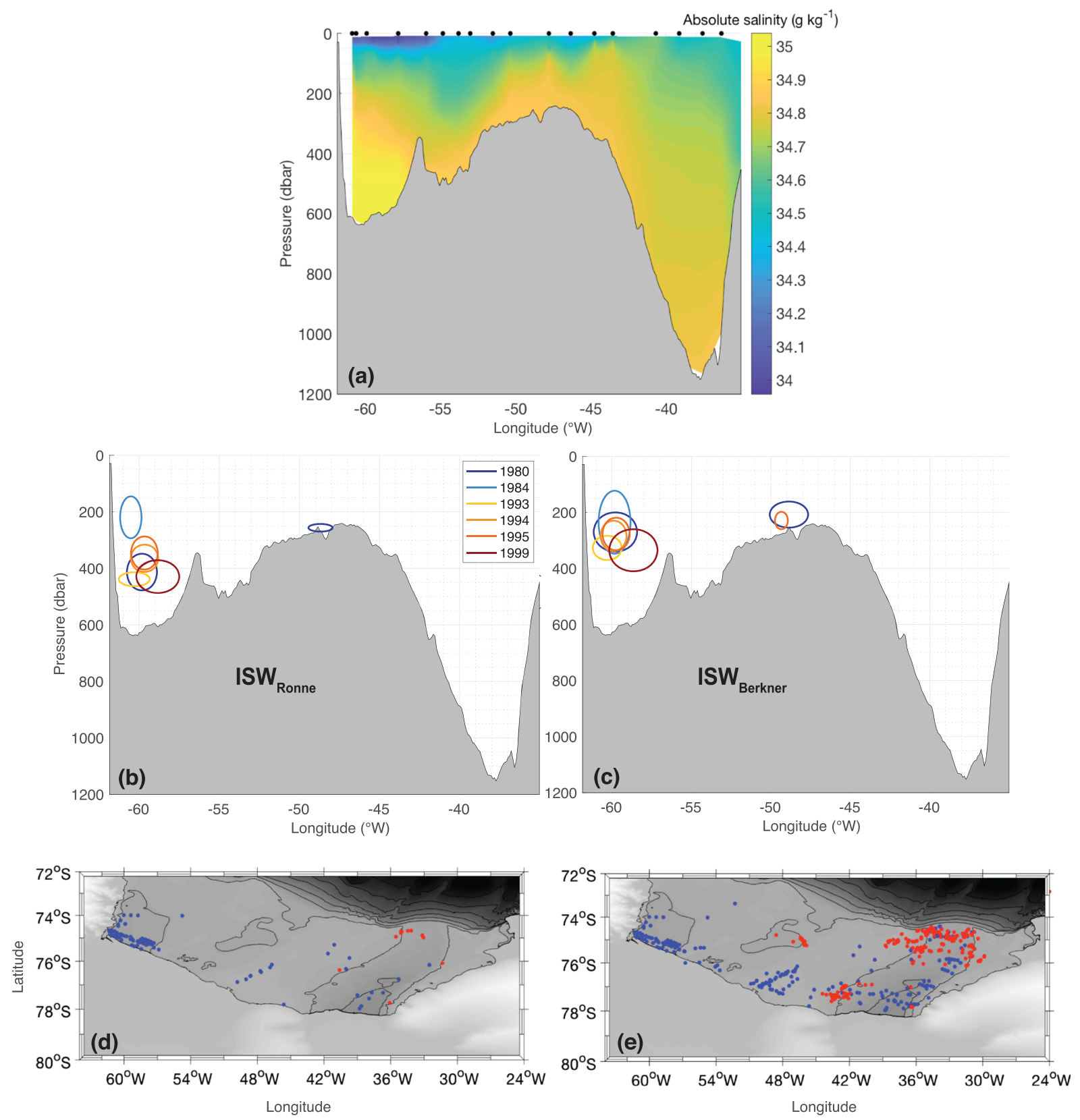

Figure 4. (a) Absolute salinity directly in front of FRIS sampled in 1995 (same transects as in Figure 2f). The black dots show the position of the sampled profiles before interpolation. (b, c) Ellipses of the longitude and depth location (mean \pm standard deviation) of salinity observations at (b) $S_{A}=34.92$ $\pm 0.01 \mathrm{~g} / \mathrm{kg}$, and (c) $S_{A}=34.87 \pm 0.01 \mathrm{~g} / \mathrm{kg}$, along six historical transects in front of FRIS, in (dark blue) 1980, (light blue) 1984, (yellow ) 1993, (orange) 1994, (light red) 1995, and (dark red) 1999. (d, e) Maps of the continental shelf showing the position of all measurements that have sampled water masses of salinity at (d) $S_{A}=34.92 \pm 0.01 \mathrm{~g} / \mathrm{kg}$, and (e) $S_{A}=34.87 \pm 0.01 \mathrm{~g} / \mathrm{kg}$, in the past. Blue dots correspond to ship-based measurements, and red dots correspond to the observations from instrumented seals.

sources are set, we can quantify how each HSSW end member source interacted with the ice shelf to form each flavor of ISW; that is, how much glacier ice has melted into $\mathrm{HSSW}_{\text {Ronne }}\left(\mathrm{HSSW}_{\text {Berkner }}\right)$ to form $\mathrm{ISW}_{\text {Ronne }}$ $\left(\mathrm{ISW}_{\text {Berkner }}\right)$.

\subsection{Fraction of Ice Melt and Freeze Into the Two Flavors of ISW}

We first evaluate the range of possible ice shelf characteristics that potentially interacted with each HSSW end member. Equations (5) and (6) (section 2.5.2) provide the relationship between $\delta^{18} \mathrm{O}$ and DO ice shelf characteristics based on the observed characteristics of the identified HSSW-ISW pairs $\left(\mathrm{HSSW}_{\text {Ronne }}\right.$ 


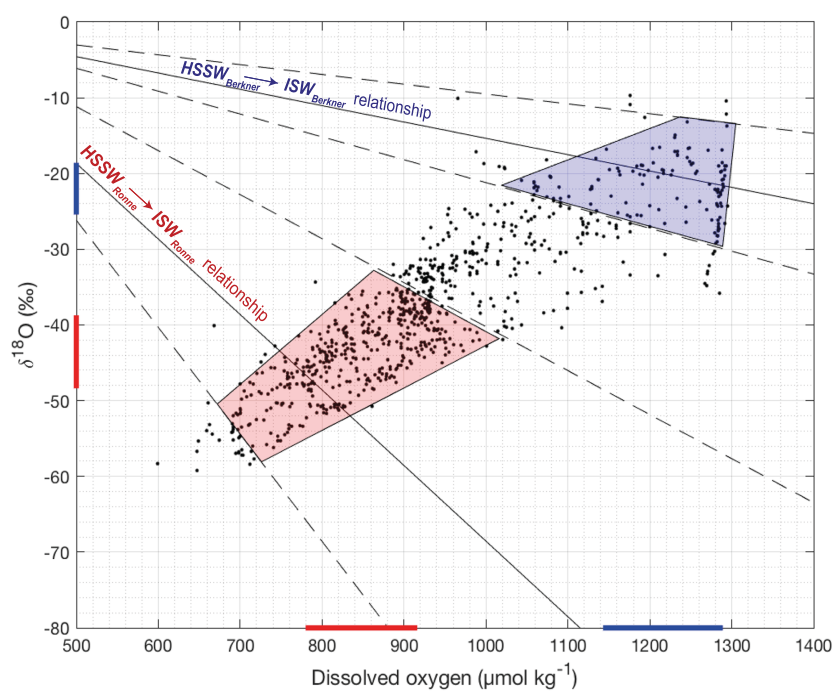

Figure 5. Scatter plot showing (back dots) the parameter space covered by the Antarctica Ice Sheet in $\delta^{18} \mathrm{O}-\mathrm{DO}$ space, estimated from glaciological historical observations (the glaciological constraint, see section 2.5.1; Martinerie et al., 1992; Masson-Delmotte et al., 2008). The ice sheet characteristics that interacted with $\mathrm{HSSW}_{\text {Ronne }} \rightarrow I_{\text {Ronne }}$, and $\mathrm{HSSW}_{\text {Berkner }} \rightarrow I S W_{\text {Berkner }}$, follow each a known relationship that is inferred from ocean observations, and which is superimposed as plain black line \pm standard deviation envelops, as black dashed lines (the ocean constraint, see section 2.5.2). The mean and standard deviation of all points within the intersection of the glaciological constraint and the ocean constraint provide estimates of the characteristics of the ice that interacted with (red shading) $\mathrm{HSSW}_{\text {Ronne }} \rightarrow I S W_{\text {Ronne }}$, and (blue shading) HSSW $\mathrm{Herkner} \rightarrow I S W_{\text {Berkner }}$.

to $\mathrm{ISW}_{\text {Ronne }}$; $\mathrm{HSSW}_{\text {Berkner }}$ to $\mathrm{ISW}_{\text {Berkner }}$ ). These two relationships are shown in Figure 5 as black lines and represent the range of possible meteoric ice characteristics that $\mathrm{HSSW}_{\text {Ronne }}$ or $\mathrm{HSSW}_{\text {Berkner }}$ interact with, based on the oceanographic constraint. Notably, these two domains do not overlap. We also compute a standard deviation around the mean relationship based on the standard deviation of the two HSSW end members and of the two flavors of ISW characteristics. In addition, we derive the possible $\delta^{18} \mathrm{O}$-DO space for Antarctic ice (black dots in Figure 5) based on the relationship between $\delta^{18} \mathrm{O}$ and DO estimated from glaciological constraint (see section 2.5.1). The range of possible ice shelves properties that interacted with $\mathrm{HSSW}_{\text {Ronne }}$ or $\mathrm{HSSW}_{\text {Berkner }}$ is defined as the mean and standard deviation of all black dots in Figure 5 within the intersection of the oceanographic and glaciological constraints.

The ice shelf that interacted with $\mathrm{HSSW}_{\text {Ronne }}$ to form $\mathrm{ISW}_{\text {Ronne }}$ most likely had a $\delta^{18} \mathrm{O}$ of $-44 \pm 5 \%$, associated with DO of $850 \pm 70 \mu \mathrm{mol} / \mathrm{kg}$ (red shading in Figure 5). In contrast, the ice shelf that interacted with $\mathrm{HSSW}_{\text {Berkner }}$ to form $\mathrm{ISW}_{\text {Berkner }}$ most likely had a $\delta^{18} \mathrm{O}$ of $-22 \pm 3 \%$, associated with DO of $1,220 \pm 70 \mu \mathrm{mol} / \mathrm{kg}$. This analysis suggests that $\mathrm{HSSW}_{\text {Ronne }}$ interacted with an older ice, formed at higher altitude than the ice that interacted with $\mathrm{HSSW}_{\text {Berkner }}$. Only very few ice cores have measured $\delta^{18} \mathrm{O}$ on FRIS, but we note that $\delta^{18} \mathrm{O}$ of order $-40 \%$ are typical values recorded at depth in ice cores over the ice sheet (Casado et al., 2018) and that $\delta^{18} \mathrm{O}$ of order $-20 \%$ are values consistent with those recorded in an ice core near the front of FRIS (Graf et al., 1988). While much uncertainty exists in the spatial variability of basal $\delta^{18} \mathrm{O}$ characteristics of ice, lower values of $\delta^{18} \mathrm{O}$ could be associated with ice closer to the ice front (consistent with][and arguably because ice nearer the ice-front might locally form on the ice shelf by ice compaction ; Graf et al., 1988). This would be consistent with $\mathrm{HSSW}_{\text {Berkner }}$ circulating less far in the ice shelf cavity than $\mathrm{HSSW}_{\text {Ronne }}$.

We can now evaluate how those ice shelf $\delta^{18} \mathrm{O}$ characteristics are consistent with salinity change from $\mathrm{HSSW}_{\text {Ronne }}$ to $\mathrm{ISW}_{\text {Ronne }}$ and from $\mathrm{HSSW}_{\text {Berkner }}$ to $\mathrm{ISW}_{\text {Berkner }}$ (using equations (7) and (8) and mass conservation; section 2.5.2). We find that both $\mathrm{ISW}_{\text {Ronne }}$ and $\mathrm{ISW}_{\text {Berkner }}$ are composed of the same amount of ice shelf net mass loss $\left(f_{\text {melt }}-f_{\text {freeze }}\right)$, representing $0.4 \%$ of ISW mass. These fractions of mass contribution from the ice shelf for ISW Ronne and ISW $_{\text {Berkner }}$ decompose however differently into $f_{\text {melt }}$ and $f_{\text {freeze }}$ (see section 3.2 and Figure 6). $\mathrm{ISW}_{\text {Ronne }}$ is associated with a melt of meteoric ice of $0.4 \pm 0.004 \%$, and a net freeze $/ \mathrm{melt}$ of marine ice of $0.01 \pm 0.004 \%$. In contrast, we estimate that ISW $_{\text {Berkner }}$ is composed of $1.4 \pm 0.04 \%$ of meteoric 


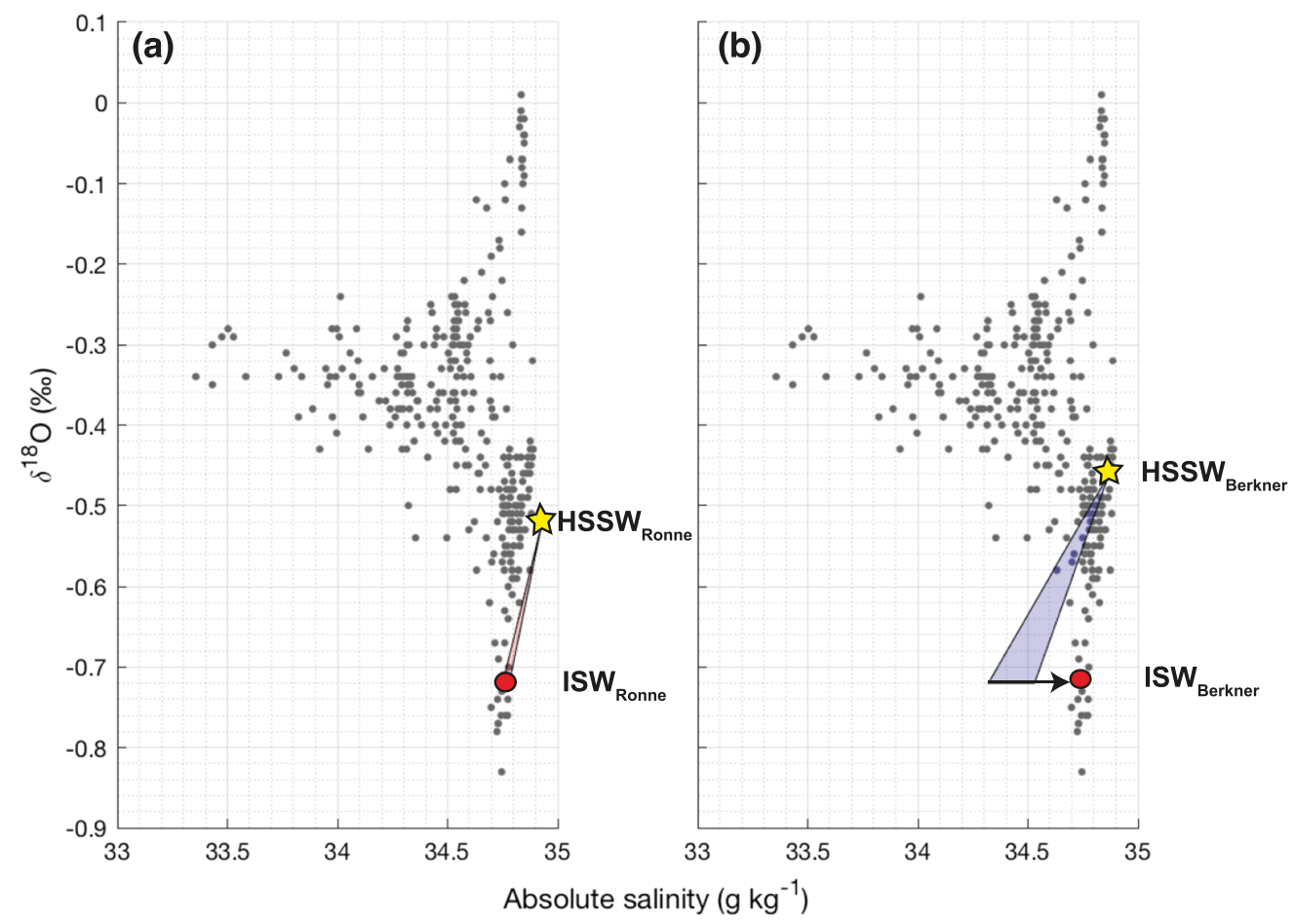

Figure 6. $\delta^{18} \mathrm{O}-S_{A}$ characteristics of (gray dots) all observations sampled in 2017 (observations corresponding transects shown in Figures 2a-2e). The characteristics of (a) HSSW Ronne $_{\text {and }}$ and $\mathrm{ISO}_{\text {Rone }}$ and (b) $\mathrm{HSSW}_{\text {Berkner }}$ and $\mathrm{ISW}_{\text {Berkner }}$ are superimposed as yellow star for HSSW and red dots for ISW. (a) An ice shelf of $\delta^{18} \mathrm{O}$ of $-44 \pm 5 \%$ melting into $\mathrm{HSSW}_{\text {Ronne }}$ would transform the characteristics of $\mathrm{HSSW}_{\text {Ronne }}$ following the red shaded polygon. The black right arrow represents the salinification that would need to occur as refreezing, for salinity of the resulting water mass to match the salinity of ISW Ronne. $_{\text {. }}$ (b) Similarly, an ice shelf of $\delta^{18} \mathrm{O}$ composition of $-22 \pm 3 \%$ melting into HSSW Berkner $_{\text {would }}$ transform the characteristics of HSSW $_{\text {Berkner }}$ following the blue shaded polygon. The black right arrow represents the salinification induced by the refreezing that produces ISW $_{\text {Berkner }}$.

ice meltwater, and a net freeze/melt of marine ice of $1 \pm 0.05 \%$ (i.e., freeze of marine ice dominating over melt of marine ice; Figure 6b).

\subsection{Composition of the ISW Mixture on the Continental Shelf}

We have described above how the two different flavors of ISW observed at the front of Filchner Ice Shelf are formed from different sources ranging between two HSSW end members, which originate from two main regions: Ronne Trough and Berkner Bank. We also find that the flavors of ISW are composed of a small proportion of meteoric ice meltwater and marine ice refreeze, the ice shelf contributing ultimately to $0.4 \%$ of ISW mass. We now focus on the fate of these outflowing ISW types during their northward pathways on the continental shelf. In particular, we seek to understand how the flavors of ISW emerging from under the ice shelf mix with other water masses on the continental shelf to form the ISW mixture traveling over the continental sill. Darelius et al. (2014) suggest that the core of ISW $_{\text {Ronne }}$ flowing along the western flank of the Filchner Depression does not reach the sill as previously thought (Foldvik et al., 2001; Nicholls et al., 2001). We will therefore retain only the eastern flavor of ISW characteristics observed at the front of Filchner Ice Shelf ( $\mathrm{ISW}_{\text {Berkner }}$ ), which is likely the flavor of ISW that feeds the ISW mixture we sampled as it flows northward along the eastern flank of the Filchner Depression (Darelius et al., 2014; Darelius \& Sallée, 2018).

We now estimate the proportions of the four water mass end members: $\mathrm{HSSW}_{\text {Berkner }}, \mathrm{ISW}_{\text {Berkner }}$, WW, and WDW that mix together on the continental shelf to ultimately form the ISW mixture overflowing in the deep ocean on the continental slope. A simple system of equations describes linear mixing of a set of conservative tracers associated with each of these water masses (equation (11) and see section 2.6). Three conservative tracers are considered $\left(S_{A}, \delta^{18} \mathrm{O}\right.$, and DO) in addition to mass conservation, to solve for ISW mixture composition as fractions of the four water mass end members. We solve this system of equations for each of the 

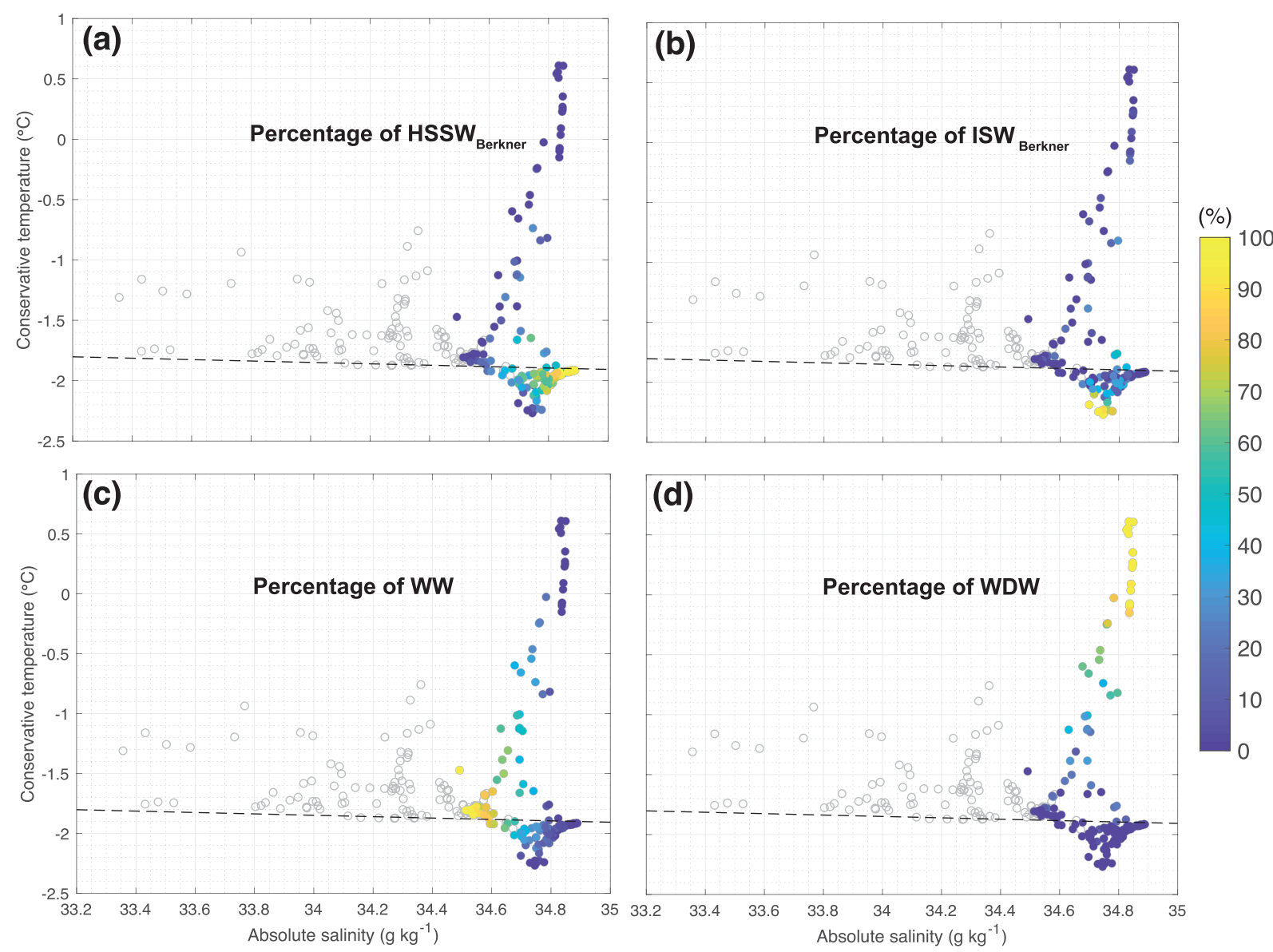

Figure 7. $\Theta-S_{A}$ characteristics of all observations sampled in 2017 (same as Figure 3a), but showing in color the percentage contribution of (a) HSSW ${ }_{B e r k n e r}$, (b) $\mathrm{ISW}_{\text {Berkner }}$, (c) WW, and (d) WDW sources, within each observation sampled at depth deeper than $200 \mathrm{~m}$, deduced from a mass balance system of equations (equation (11), see section 3.3). The gray circle shows $\Theta-S_{A}$ characteristics for observations shallower than $200 \mathrm{~m}$, and the surface freezing line is given by the black dashed line.

water samples obtained on the continental shelf. The upper $200 \mathrm{~m}$ of the water column is excluded from this analysis, as DO, $S_{A}$, and $\delta^{18} \mathrm{O}$ are unlikely to be conserved in this upper layer, as a result of biology affecting DO, and of sea ice and precipitation affecting salinity and $\delta^{18} \mathrm{O}$. The definition of the characteristics of each water mass end member plays an important role in the outcome of this calculation. Definitions of $\mathrm{HSSW}_{\text {Berkner }}, \mathrm{ISW}_{\text {Berkner }}$, WW, and WDW are obtained from our set of observations and summarized in Table 1 (see also section 2.4).

After solving the system of equations (11), water mass fractions are represented in a $\Theta-S_{A}$ space in order to check the results (Figure 7). Overall, the system of equations provides consistent results with increasing fractions of each component when approaching their definitions in $\Theta-S_{A}$ space. Between each water mass end member, mixing can also be visualized: modified Warm Deep Water, being mostly composed of a mix of WDW and WW (Carmack \& Foster, 1975; Foster \& Carmack, 1976); ISW, resulting mainly from a balanced mix of HSSW Berkner $_{\text {, ISW }}$ Berkner , and WW (Figure 7). The mean composition of the ISW mixture on the continental shelf represents $61 \pm 29 \%$ of $\mathrm{HSSW}_{\text {Berkner }}, 17 \pm 24 \%$ of $\mathrm{ISW}_{\text {Berkner }}, 20 \pm 25 \%$ of WW, and $1.5 \pm 3 \%$ of WDW (Figure 8a). Now, acknowledging that $\mathrm{ISW}_{\text {Berkner }}$ is a mixture of $99.6 \pm 0.09 \%$ of $\mathrm{HSSW}_{\text {Berkner }}$ and $0.4 \pm 0.09 \%$ of glacial meltwater (defined here and thereafter as the net mass of ice shelf added to the ocean in the cavity, i.e., meteoric ice melt minus marine ice refreeze; see above), the ISW mixture cascading the continental slope is ultimately composed of $78 \pm 53 \%$ of $\mathrm{HSSW}_{\text {Berkner }}, 0.1 \pm 0.1 \%$ of ice shelf meltwater, $20 \pm 25 \%$ of WW, and $1.5 \pm 3 \%$ of WDW (Figure 8a). Interestingly, the proportion of WDW mixing into ISW is small but not 0 . When looking at the meridional evolution of the WDW signal on the continental shelf, it is clear that its fraction increases northward, being mostly absent in the southernmost hydrographic sections (sections 1-3) and increasing up to $10 \pm 4 \%$ for section 5 , as ISW mixture sinks along the continental slope. This northward 

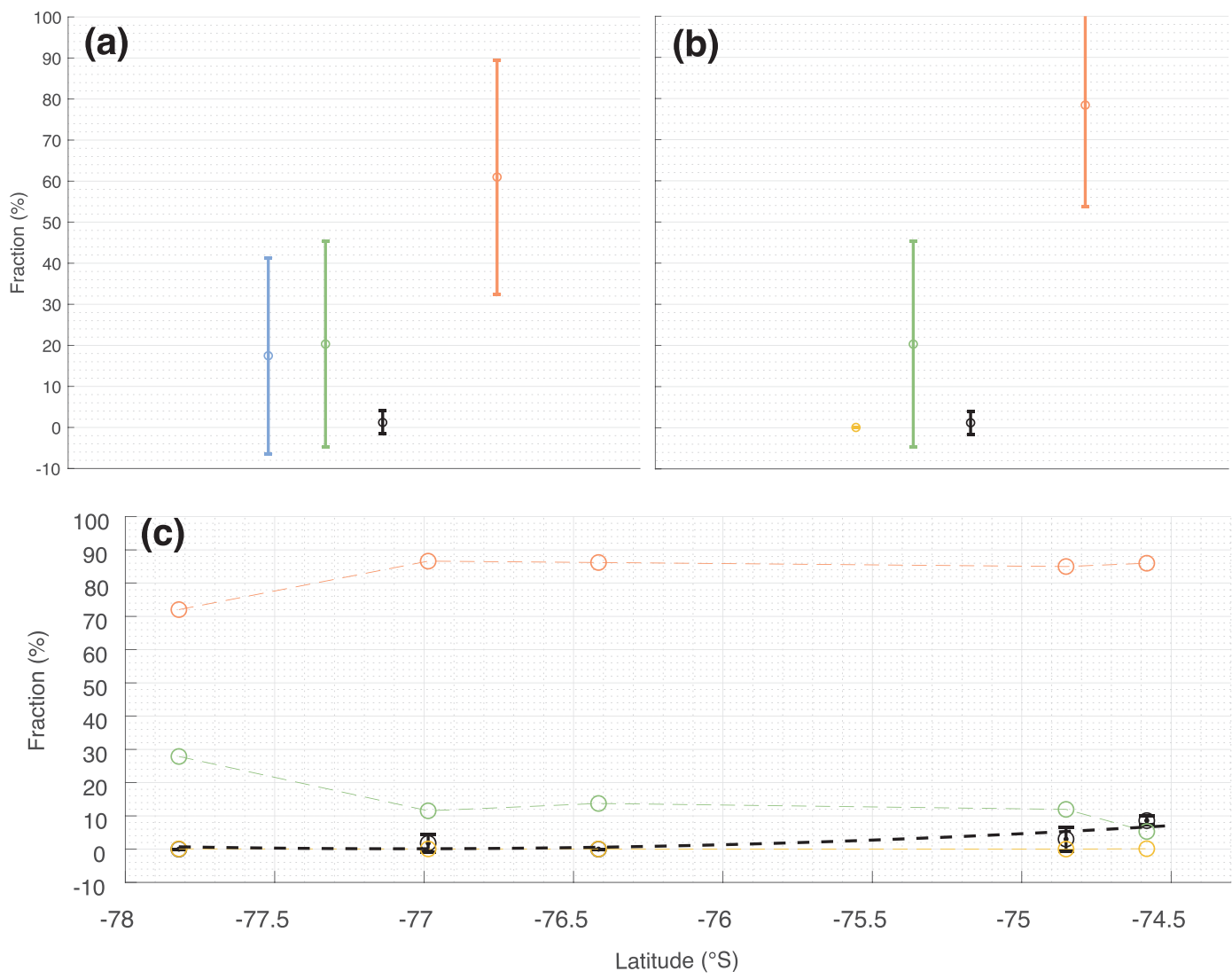

Figure 8. (a) Mean ( \pm standard deviation) percentage of each constituent of ISW over the entire continental shelf:

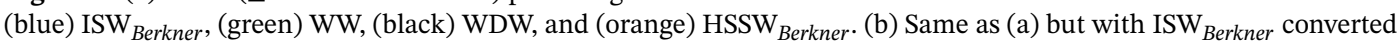
into HSSW $_{\text {Berkner }}$ and (yellow) glacial meltwater. (c) Same as (b) but split up by transect and shown as a function of the mean latitude of each transect on the continental shelf.

increase suggests an entrainment of WDW into ISW near and along the continental slope. When considering the resulting fraction interpolated on the continental slope section (Figure 9b), the overflowing ISW is clearly highlighted as a mixture of the dense $\operatorname{HSSW}_{\text {Berkner }}$ (Figure 9a) and $\operatorname{ISW}_{\text {Berkner }}$ (Figure 9b), entraining above-lying WDW, as it descends the slope and exits the Filchner Depression (Figure 9d). We also clearly note a southward intrusion of WDW on the continental shelf, mixing with WW, directly above the northward flowing ISW.

As an estimate of the sensitivity of the mass balance calculation, we rerun the exact same system of equations (equation (11)) but replaced the DO equation by a conservative temperature equation (essentially replacing all DO into $\Theta$, in equation (11)). The overall resulting ISW mixture decomposition falls within the standard deviation envelop of the results presented above, giving us confidence in the robustness of the decomposition.

\section{Discussion and Conclusion}

The influence of FRIS on the characteristics of cold and dense waters produced in the southern Weddell Sea is documented from a set of observations sampled in 2017. We first investigated how two different identified HSSW end members interacted with ice shelf to produce different flavors of ISW and then described how the slightly lighter version of ISW mixes with other water masses on the continental shelf to produce the ISW mixture, which ultimately sinks along the continental slope as a precursor of AABW.

Different flavors of ISW emerge from in the ice shelf cavity at the eastern and western sides of the Filchner Depression as an isotopically depleted and supercooled water mass (blue patches on Figure 2a). The eastern and western ISW types have, however, distinct characteristics and have been shown to be associated with 

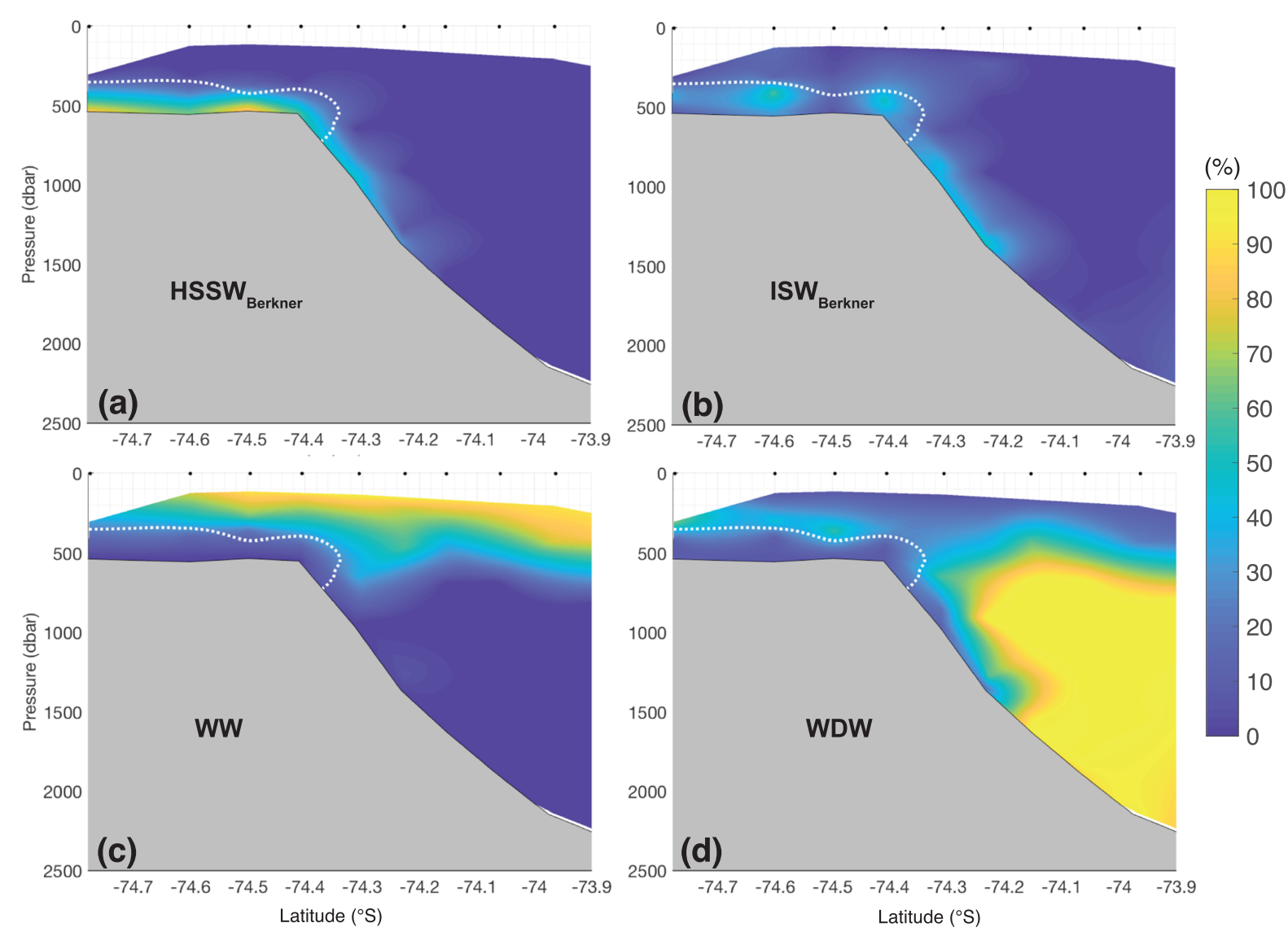

Figure 9. Percentage contributions of source water masses in the meridional section crossing the continental slope (corresponding to Figure 2e) shown as percentage of (a) $\mathrm{HSSW}_{\text {Berkner }}$, (b) $\mathrm{ISW}_{\text {Berkner }}$, (c) WW, and (d) WDW sources. In each panel, the white dashed line represents the upper boundary of the ISW mixture $(\Theta<$ surface freezing point), flowing on the continental slope.

distinct dynamics (Darelius \& Sallée, 2018). We document two main flavors of ISW: the freshest version $\left(\mathrm{ISW}_{\text {Berkner }}\right.$ ), which we estimate to originate from a mix of ice shelf meltwater with a HSSW end member of absolute salinity around $\sim 34.87 \mathrm{~g} / \mathrm{kg}\left(\mathrm{HSSW}_{\text {Berkner }}\right)$; and the saltiest version $\left(\mathrm{ISW}_{\text {Ronne }}\right.$ ), which we estimate to originate from a mix of ice shelf meltwater with a HSSW end member of absolute salinity around $\sim 34.93 \mathrm{~g} / \mathrm{kg}$ $\left(\mathrm{HSSW}_{\text {Ronne }}\right)$. While the ISW observed at the eastern side of the Filchner Depression has characteristics of $\mathrm{ISW}_{\text {Berkner }}$, the ISW observed at the western side shows a range of characteristics suggesting that it results from a mixture of $\mathrm{ISW}_{\text {Ronne }}$ and $\mathrm{ISW}_{\text {Berkner }}$, mixing presumably happening in the ice shelf cavity.

Using a combination of ocean and ice sheet observations of $\delta^{18} \mathrm{O}$ and DO, we show that $\mathrm{HSSW}_{\text {Ronne }}$ interacted with an ice shelf of significantly different characteristics than the ice shelf that $\mathrm{HSSW}_{\text {Berkner }}$ interacted with. The mean ice shelf composition contributing to $\mathrm{HSSW}_{\text {Ronne }}$ has significantly lower $\delta^{18} \mathrm{O}$ composition and DO concentration $\left(-44 \pm 5 \% ; 850 \pm 70 \mu \mathrm{mol} / \mathrm{kg}\right.$ ) than the ice shelf encountered by $\mathrm{HSSW}_{\text {Berkner }}$ $(-22 \pm 3 \% ; 1,220 \pm 70 \mu \mathrm{mol} / \mathrm{kg})$. These results suggest that $\mathrm{HSSW}_{\text {Ronne }}$ and $\mathrm{HSSW}_{\text {Berkner }}$ interact with different basal ice characteristics and therefore might follow distinct pathways in the ice shelf cavity. In addition, the estimated ice shelf properties in $\delta^{18} \mathrm{O}$ and DO that have contributed to each HSSW end member suggest that $\mathrm{HSSW}_{\text {Berkner }}$ has been influenced by an ice shelf formed at lower altitude and latitude than $\mathrm{HSSW}_{\text {Ronne }}$. We note, however, that due to the very sparse measurements of $\delta^{18} \mathrm{O}$ in ice cores over FRIS we cannot conclude robustly on specific pathways based on basal ice characteristics estimates. We can only conclude that

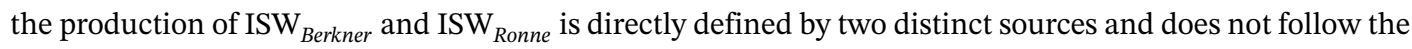
same pathway within the cavity. Consistent, sub-ice shelf observations in the southern Filchner Ice Shelf cavity, far from the ice front, do not show any hint of water masses consistent with HSSW $_{\text {Berkner }}$, while they are consistent with $\mathrm{HSSW}_{\text {Ronne }}$ (T. Hatterman, personal communication, September 2018; Huhn et al., 2018; Nicholls et al., 2001). The most important limitation of our data set is the lack of observations inside the 
cavity along circulation pathways. With only observations of the inflows and outflows, any interpretation of mixing processes between them inside the cavity is very limited. Changes of characteristics from HSSW end members to ISW types suggest that both $\mathrm{ISW}_{\text {Ronne }}$ and $\mathrm{ISW}_{\text {Berkner }}$ are composed of $0.4 \%$ glacial meltwater. We however estimate that there is more meteoric ice that has melted in $\mathrm{ISW}_{\text {Berkner }}$ than $\mathrm{ISW}_{\text {Ronne }}$ $\left(1.4 \pm 0.04 \%\right.$ vs. $0.4 \pm 0.004 \%$, respectively). On the other hand, $\mathrm{ISW}_{\text {Berkner }}$ is subject to net refreeze of marine ice $(1 \pm 0.05 \%)$, while freezing and melting of marine ice compensate each other (net value of $0.01 \pm 0.004 \%$ ) for $\mathrm{ISW}_{\text {Ronne }}$. Estimates of outward ISW volume transport at Filchner Ice Front is highly uncertain, but an order of O(1-2) Sv appears sensible based on previous studies (Darelius et al., 2014; Darelius \& Sallée, 2018; Foldvik et al., 2004). Combined with our estimate of about $0.4 \%$ of glacial meltwater content within ISW types, we estimate that they would transport the equivalent of $\mathrm{O}(100-200) \mathrm{Gt} /$ year of ice, very much consistent with the estimates of net melt of FRIS from satellite data (155 $\pm 36 \mathrm{Gt} /$ year; Rignot et al., 2013). In addition, observations of noble gas under the ice shelf show results in good agreement with ours (Huhn et al., 2018). In their study, Huhn et al. (2018) show that most of the estimated refreezing is considered to be associated with $\mathrm{HSSW}_{\text {Berkner }}$, with melting and refreezing in the cavity evaluated as $2 \pm 1.5 \%$ and $1.7 \pm 0.9 \%$ respectively.

Once ISW $_{\text {Berkner }}$ emerges from beneath the cavity, it mixes with ambient water masses to form an ISW mixture, which flows northward on the eastern flank of the Filchner Depression, before cascading the continental slope. The pathway of ISW $_{\text {Ronne }}$ after escaping the ice shelf cavity is less clear. It likely flows at depth in the Filchner Depression in a cyclonic gyre circulation (Carmack \& Foster, 1975; Darelius et al., 2014) and probably contributes to the properties of HSSW $_{\text {Berkner }}$. Because of the frequent presence of ice during the austral summer on the western side of the Filchner Depression, we were not able to obtain observations in 2017 to further document the evolution of ISW $_{\text {Ronne }}$. The observations obtained on the eastern flank of the Filchner Depression are likely more relevant to $\mathrm{ISW}_{\text {Berkner }}$. Based on these observations, we find that the ISW mixture in the Filchner Depression is composed of a very large majority of $\mathrm{HSSW}_{\text {Berkner }}(78 \pm 53 \%$ ), which mixes with WW $(20 \pm 25 \%)$, and glacial meltwater $(0.1 \pm 0.1 \%)$ outflowing from the ice shelf cavity within $\mathrm{ISW}_{\text {Berkner }}$. In addition, one notes an increasing fraction of WDW entrained into the ISW mixture at the continental sill and slope. We estimate that $\sim 10 \%$ of the volume of the ISW mixture along the continental slope is composed of WDW, clearly showing a signature of entrainment. The ISW descending the continental slope is a Filchner Depression's manifestation of Weddell Sea Bottom Water. This water mass flows at the bottom of the Weddell Sea and is too dense to escape the Weddell Gyre through its main gateway, the South Scotia Ridge. It is therefore thought to circulate in the gyre until it mixes with overlying WDW (Foldvik et al., 2004; Nicholls et al., 2009) to form Weddell Sea Deep Water, which is generally lighter and is then exported toward the Scotia Sea to ultimately contribute to AABW.

While this paper does not investigate time variability and trends, our results can provide insights into how ISW might be sensitive to potential climate variability or future trends. By decomposing the ISW into its parent water masses, it appears clearly that subtle changes in sea ice regime would have major consequences for its characteristics, through changing the properties of HSSW. Ice shelf meltwater represents only $0.1 \pm 0.1 \%$ of the volume of ISW; however, small changes in the proportion of ice shelf meltwater as expected under climate change scenarios (Naughten et al., 2018) can also significantly affect the characteristics of ISW. For example, adding another $0.1 \%$ of meteoric ice meltwater to ISW would significantly reduce its salinity on the order of $0.03 \mathrm{~g} / \mathrm{kg}$, diminishing its density, with consequences for AABW characteristics.

\section{Appendix A: Comparison of Stable Water Isotope Data Sets}

In this study, a stable water isotopes data set from a cruise in 1995 has been used to provide a baseline in order to compare to our data as well as to provide estimate of $\delta^{18} \mathrm{O}$ for HSSW in the Ronne Trough. Both data sets appear to be consistent despite the 20 years between the two cruises and different methods for isotope analysis (Figure A1). $\delta^{18} \mathrm{O}$ from 1995 was determined by water sample equilibrated with $\mathrm{CO}_{2}$ gas by using an online connected Finnigan MAT Delta-S mass spectrometer with a reproducibility of 0.03\%o (Mackensen, 2001b). Water samples characterized by high salinity (around $35 \mathrm{~g} / \mathrm{kg}$; Figure A1) are from the cruise in 1995 in front of Ronne Ice Shelf where HSSW $_{\text {Ronne }}$ is formed, a region not observed during the 2017 cruise. We therefore apply no offset correction to these data, before using the 1995 data set in combination with the 2017 observations. The good comparison of these two data sets gives us confidence in the quality of the data sets. 


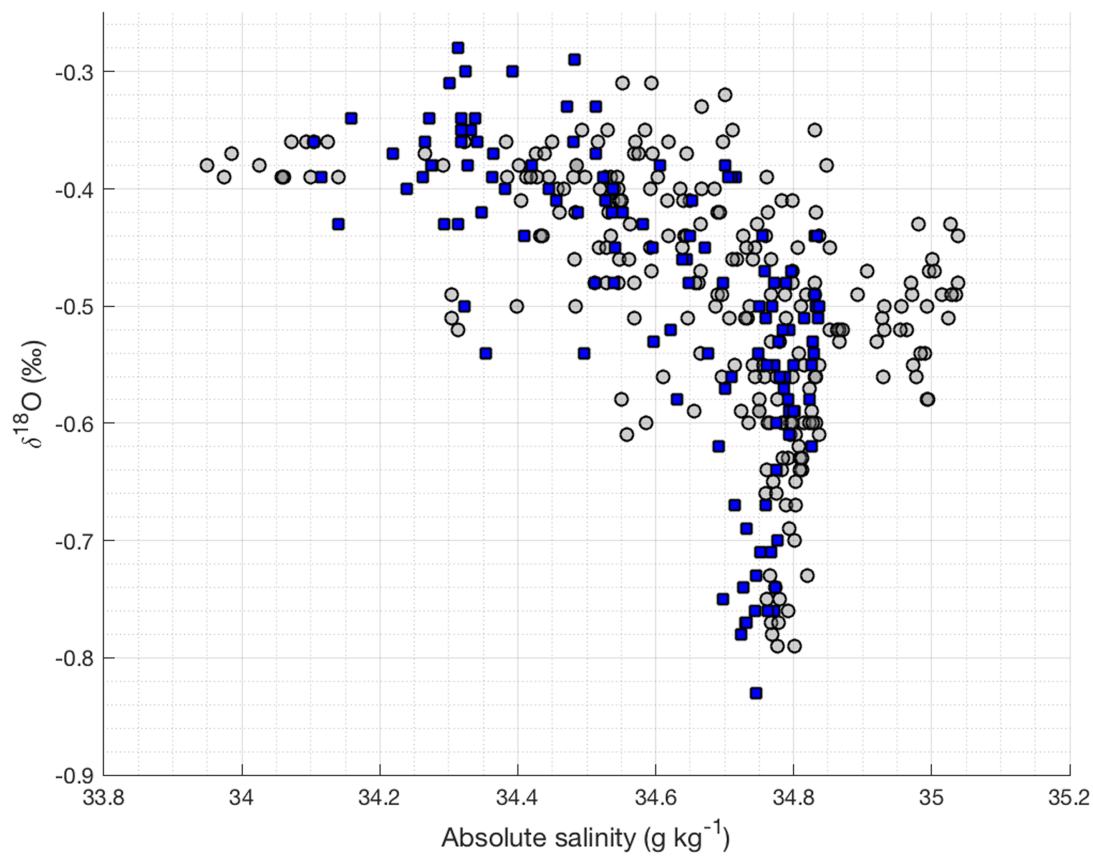

Figure A1. $\delta^{18} \mathrm{O}-S_{A}$ characteristics of (blue squares) observations sampled in front of Filchner Ice Shelf in 2017 (observations corresponding transects shown in Figure 2a) and (gray circles) observations sampled in front of FRIS in 1995 (observations corresponding to the transects shown in Figure 2f).

\section{Acknowledgments}

This project has received funding from the European Research Council (ERC) under the European Union's Horizon 2020 research and innovation program (Grant Agreement 637770). The authors gratefully thank the captain and the crew of RRS James Clark Ross for their help in acquiring the 2017 data set as part of the Wapiti Cruise JR16004. Thanks to N. Jourdain and M. Meredith for fruitful discussions. We are indebted to Tore Hattermann, two anonymous reviewers and the Editor Dr. Laurence Padman for their detailed comments on earlier versions of this manuscript. Oxygen isotopes, temperature, and salinity from Mackensen (2001b) can be obtained from https://doi.pangaea.de/10.1594/ PANGAEA.756222 and https://doi. pangaea.de/10.1594/PANGAEA.55750; oxygen isotopes, temperature, and salinity bottle data from the 2017's Wapiti cruise are available online (https://doi.org/10.17882/71186).

\section{References}

Benetti, M., Sveinbjörnsdóttir, A., Ólafsdóttir, R, Leng, M., Arrowsmith, C., Debondt, K., et al. (2017). Inter-comparison of salt effect correction for $\delta^{18} \mathrm{O}$ and $\delta^{2} \mathrm{H}$ measurements in seawater by CRDS and IRMS using the gas- $\mathrm{H}_{2} \mathrm{O}$ equilibration method. Marine Chemistry, 194, 114-123. https://doi.org/10.1016/j.marchem.2017.05.010

Bentley, M. J., \& Anderson, J. B. (1998). Glacial and marine geological evidence for the ice sheet configuration in the Weddell Sea-Antarctic Peninsula region during the Last Glacial Maximum. Antarctic Science, 10(3), 309-325. https://doi.org/10.1017/S0954102098000388

Bombosch, A., \& Jenkins, A. (1995). Modeling the formation and deposition of frazil ice beneath Filchner-Ronne Ice Shelf. Journal of Geophysical Research, 100(C4), 6983-6992. https://doi.org/10.1029/94JC03224

Brown, P. J., Meredith, M. P., Jullion, L., Naveira Garabato, A., Torres Valdes, S., Holland, P., et al. (2014). Freshwater fluxes in the Weddell Gyre: Results from $\delta^{18} \mathrm{O}$. Philosophical Transactions of the Royal Society A: Mathematical, Physical and Engineering Sciences, 372(2019), 20130298. https://doi.org/10.1098/rsta.2013.0298

Carmack, E. C., \& Foster, T. D. (1975). Circulation and distribution of oceanographic properties near the Filchner Ice Shelf. Deep Sea Research and Oceanographic Abstracts, 22(2), 77-90. https://doi.org/10.1016/0011-7471(75)90097-2

Casado, M., Landais, A., Picard, G., Münch, T., Laepple, T., Stenni, B., et al. (2018). Archival processes of the water stable isotope signal in East Antarctic ice cores. The Cryosphere, 12(5), 1745-1766. https://doi.org/10.5194/tc-12-1745-2018

Darelius, E., Fer, I., \& Nicholls, K. W. (2016). Observed vulnerability of Filchner-Ronne Ice Shelf to wind-driven inflow of warm deep water Nature communications, 7, 12300. https://doi.org/10.1038/ncomms12300

Darelius, E., Makinson, K., Daae, K., Fer, I., Holland, P. R., \& Nicholls, K. W. (2014). Hydrography and circulation in the Filchner Depression, Weddell Sea, Antarctica. Journal of Geophysical Research: Oceans, 119, 5797-5814. https://doi.org/10.1002/2014JC010225

Darelius, E., \& Sallée, J.-B. (2018). Seasonal outflow of Ice Shelf Water across the front of the Filchner Ice Shelf, Weddell Sea, Antarctica. Geophysical Research Letters, 45, 3577-3585. https://doi.org/10.1002/2017GL076320

Darelius, E., Smedsrud, L., Østerhus, S, Foldvik, A., \& Gammelsrød, T (2009). Structure and variability of the Filchner overflow plume. Tellus A: Dynamic Meteorology and Oceanography, 61(3), 446-464. https://doi.org/10.1111/j.1600-0870.2009.00391.x

Darelius, E., Strand, K. O., Østerhus, S., Gammeslrød, T., Årthun, M., \& Fer, I. (2014). On the seasonal signal of the Filchner overflow, Weddell Sea, Antarctica. Journal of Physical Oceanography, 44(4), 1230-1243. https://doi.org/10.1175/JPO-D-13-0180.1

DeConto, R. M., \& Pollard, D. (2016). Contribution of Antarctica to past and future sea-level rise. Nature, 531(7596), 591. https://doi.org/ $10.1038 /$ nature 17145

DeVries, T., \& Primeau, F. (2011). Dynamically and observationally constrained estimates of water-mass distributions and ages in the global ocean. Journal of Physical Oceanography, 41(12), 2381-2401. https://doi.org/10.1175/JPO-D-10-05011.1

Dupont, T., \& Alley, R. (2005). Assessment of the importance of ice-shelf buttressing to ice-sheet flow. Geophysical Research Letters, 32, L04503. https://doi.org/10.1029/2004GL022024

Edwards, T. L., Brandon, M. A., Durand, G., Edwards, N. R., Golledge, N. R., Holden, P. B., et al. (2019). Revisiting Antarctic ice loss due to marine ice-cliff instability. Nature, 566(7742), 58-64. https://doi.org/10.1038/s41586-019-0901-4

Foldvik, A., Gammelsrød, T, Nygaard, E., \& Østerhus, S (2001). Current measurements near Ronne Ice Shelf: Implications for circulation and melting. Journal of Geophysical Research, 106(C3), 4463-4477. https://doi.org/10.1029/2000JC000217

Foldvik, A., Gammelsrød, T., Østerhus, S., Fahrbach, E., Rohardt, G., Schröder, M., et al. (2004). Ice Shelf Water overflow and bottom water formation in the southern Weddell Sea. Journal of Geophysical Research, 109, C02015. https://doi.org/10.1029/2003JC002008 
Foldvik, A., Gammelsrød, T, \& Tørresen, T (1985). Circulation and water masses on the southern Weddell Sea Shelf. Oceanology of the Antarctic continental shelf, 43, 5-20. https://doi.org/10.1029/AR043p0005

Foster, T. D., \& Carmack, E. C. (1976). Frontal zone mixing and Antarctic Bottom Water formation in the southern Weddell Sea. Deep Sea Research and Oceanographic Abstracts, 23(4), 301-317. https://doi.org/10.1016/0011-7471(76)90872-X

Gade, H. G. (1979). Melting of ice in sea water: A primitive model with application to the Antarctic ice shelf and icebergs. Journal of Physical Oceanography, 9(1), 189-198. https://doi.org/10.1175/1520-0485(1979)009<0189:MOIISW >2.0.CO;2

Gammelsrød, T, Foldvik, A., Nøst, O., Foldvik, Ø, Anderson, L., Fogelqvist, E., et al. (1994). Distribution of water masses on the continental shelf in the southern Weddell Sea. Washington DC American Geophysical Union Geophysical Monograph Series, 85, 159-176. https://doi. org/10.1029/GM085p0159

Graf, W., Moser, H., Oerter, H., Reinwarth, O., \& Stichler, W. (1988). Accumulation and ice-core studies on Filchner-Ronne Ice Shelf, Antarctica. Annals of Glaciology, 11, 23-31. https://doi.org/10.3189/S0260305500006273

Grosfeld, K., Hellmer, H., Jonas, M., Sandhäger, H., Schulte, M., \& Vaughan, D. (1998). Marine ice beneath Filchner Ice Shelf: Evidence from a multi-disciplinary approach. Ocean, Ice, and Atmosphere: Interactions at the Antarctic Continental Margin, 75, 319-339. https:// doi.org/10.1029/AR075p0319

Hellmer, H., Kauker, F., Timmermann, R., Determann, J., \& Rae, J. (2012). Twenty-first-century warming of a large Antarctic ice-shelf cavity by a redirected coastal current. Nature, 485(7397), 225. https://doi.org/10.1038/nature11064

Herraiz-Borreguero, L., Coleman, R., Allison, I., Rintoul, S. R., Craven, M., \& Williams, G. D. (2015). Circulation of modified circumpolar deep water and basal melt beneath the Amery Ice Shelf, East Antarctica. Journal of Geophysical Research: Oceans, 120, 3098-3112. https:// doi.org/10.1002/2015JC010697

Huhn, O., Hattermann, T., Davis, P. E., Dunker, E., Hellmer, H. H., Nicholls, K. W., et al. (2018). Basal melt and freezing rates from first noble gas samples beneath an ice shelf. Geophysical Research Letters, 45, 8455-8461. https://doi.org/10.1029/2018GL079706

Jenkins, A. (1999). The impact of melting ice on ocean waters. Journal of Physical Oceanography, 29(9), 2370-2381. https://doi.org/10.1175/ 1520-0485(1999)029<2370:TIOMIO>2.0.CO;2

Jenkins, A. (2011). Convection-driven melting near the grounding lines of ice shelves and tidewater glaciers. Journal of Physical Oceanography, 41(12), 2279-2294. https://doi.org/10.1175/JPO-D-11-03.1

Jenkins, A., \& Doake, C. S. M. (1991). Ice-ocean interaction on Ronne Ice Shelf, Antarctica. Journal of Geophysical Research, 96(C1), 791-813. https://doi.org/10.1029/90JC01952

Joughin, I., \& Padman, L. (2003). Melting and freezing beneath Filchner-Ronne Ice Shelf, Antarctica. Geophysical Research Letters, 30(9), 1477. https://doi.org/10.1029/2003GL016941

Lambrecht, A., Sandhäger, H., Vaughan, D., \& Mayer, C. (2007). New ice thickness maps of Filchner-Ronne Ice Shelf, Antarctica, with specific focus on grounding lines and marine ice. Antarctic Science, 19(4), 521-532. https://doi.org/10.1017/S0954102007000661

Lehmann, M., \& Siegenthaler, U. (1991). Equilibrium oxygen- and hydrogen-isotope fractionation between ice and water. Journal of Glaciology, 37(125), 23-26. https://doi.org/10.3189/S0022143000042751

Mackensen, A. (2001a). Isotope tracers (Delta d13C) in Weddell Sea water during POLARSTERN cruise ANT-XII/3 [data set]. PANGAEA https://doi.org/10.1594/PANGAEA.55750

Mackensen, A. (2001b). Oxygen and carbon stable isotope tracers of weddell sea water masses: New data and some paleoceanographic implications. Deep Sea Research Part I: Oceanographic Research Papers, 48(6), 1401-1422. https://doi.org/10.1016/ S0967-0637(00)00093-5

Martinerie, P., Raynaud, D., Etheridge, D. M., Barnola, J.-M., \& Mazaudier, D. (1992). Physical and climatic parameters which influence the air content in polar ice. Earth and Planetary Science Letters, 112(1-4), 1-13. https://doi.org/10.1016/0012-821X(92)90002-D

Masson-Delmotte, V., Hou, S., Ekaykin, A., Jouzel, J., Aristarain, A., Bernardo, R., et al. (2008). A review of Antarctic surface snow isotopic composition: Observations, atmospheric circulation, and isotopic modeling. Journal of Climate, 21(13), 3359-3387. https://doi.org/10. 1175/2007JCLI2139.1

McDougall, T. J., Barker, P. M., Feistel, R., \& Galton-Fenzi, B. K. (2014). Melting of ice and sea ice into seawater and frazil ice formation. Journal of Physical Oceanography, 44(7), 1751-1775. https://doi.org/10.1175/JPO-D-13-0253.1

Melling, H., \& Moore, R. M. (1995). Modification of halocline source waters during freezing on the beaufort sea shelf: Evidence from oxygen isotopes and dissolved nutrients. Continental Shelf Research, 15(1), 89-113. https://doi.org/10.1016/0278-4343(94)P1814-R

Mellor, M. (1960). Temperature gradients in the Antarctic ice sheet. Journal of Glaciology, 3(28), 773-782. https://doi.org/10.3189/ S0022143000018086

Meredith, M. P. (2013). Replenishing the abyss. Nature Geoscience, 6, 166. https://doi.org/10.1038/ngeo1743

Millero, F. J., Feistel, R., Wright, D. G., \& McDougall, T. J. (2008). The composition of standard seawater and the definition of the reference-composition salinity scale. Deep Sea Research Part I: Oceanographic Research Papers, 55(1), 50-72. https://doi.org/10.1016/j. dsr.2007.10.001

Naughten, K. A., Meissner, K. J., Galton-Fenzi, B. K., England, M. H., Timmermann, R., \& Hellmer, H. H. (2018). Future projections of antarctic ice shelf melting based on CMIP5 scenarios. Journal of Climate, 31(13), 5243-5261. https://doi.org/10.1175/JCLI-D-17-0854.1

Nicholls, K., Østerhus, S., Makinson, K., Gammelsrød, T., \& Fahrbach, E. (2009). Ice-ocean processes over the continental shelf of the southern Weddell Sea, Antarctica: A review. Reviews of Geophysics, 47, RG3003. https://doi.org/10.1029/2007RG000250

Nicholls, K., Østerhus, S, Makinson, K., \& Johnson, M. (2001). Oceanographic conditions south of Berkner Island, beneath Filchner-Ronne Ice Shelf, Antarctica. Journal of Geophysical Research, 106(C6), 11,481-11,492. https://doi.org/10.1029/2000JC000350

Nøst, O. A., \& Foldvik, A. (1994). A model of ice shelf-ocean interaction with application to the Filcher-Ronne and Ross Ice Shelves. Journal of Geophysical Research, 99(C7), 14,243-14,254. https://doi.org/10.1029/94JC00769

Nøst, O. A., \& Østerhus, S. (1985). Impact of grounded icebergs on the hydrographic conditions near the Filchner Ice Shelf. https://doi. org/10.1029/AR075p0267

Oerter, H., Kipfstuhl, J., Determann, J., Miller, H., Wagenbach, D., Minikin, A., \& Graft, W. (1992). Evidence for basal marine ice in the Filchner-Ronne Ice Shelf. Nature, 358(6385), 399. https://doi.org/10.1038/358399a0

Ohshima, K. I., Fukamachi, Y., Williams, G. D., Nihashi, S., Roquet, F., Kitade, Y., et al. (2013). Antarctic Bottom Water production by intense sea-ice formation in the Cape Darnley polynya. Nature Geoscience, 6(3), 235-240. https://doi.org/10.1038/ngeo1738

Orsi, A., Johnson, G., \& Bullister, J. (1999). Circulation, mixing, and production of Antarctic Bottom Water. Progress in Oceanography, 43(1), 55-109. https://doi.org/10.1016/S0079-6611(99)00004-X

Paolo, F. S., Fricker, H. A., \& Padman, L. (2015). Volume loss from Antarctic ice shelves is accelerating. Science, 348(6232), 327-331. https:// doi.org/10.1126/science.aaa0940

Pfirman, S., Haxby, W., Eicken, H., Jeffries, M., \& Bauch, D. (2004). Drifting Arctic sea ice archives changes in ocean surface conditions. Geophysical Research Letters, 31, L19401. https://doi.org/10.1029/2004GL020666 
Renfrew, I. A., King, J. C., \& Markus, T. (2002). Coastal polynyas in the southern Weddell Sea: Variability of the surface energy budget. Journal of Geophysical Research, 107(C6), 3063. https://doi.org/10.1029/2000JC000720

Rignot, E., Jacobs, S., Mouginot, J., \& Scheuchl, B. (2013). Ice-shelf melting around Antarctica. Science, 341(6143), 266-270. https://doi. org/10.1126/science.1235798

Rignot, E., Mouginot, J., \& Scheuchl, B. (2011). Ice flow of the Antarctic ice sheet. Science, 333(6048), 1427-1430. https://doi.org/10.1126/ science. 1208336

Rippin, D. M., Bamber, J. L., Siegert, M. J., Vaughan, D. G., \& Corr, H. F. (2004). The role of ice thickness and bed properties on the dynamics of the enhanced-flow tributaries of Bailey Ice Stream and Slessor Glacier, East Antarctica. Annals of Glaciology, 39, 366-372. https://doi. org/10.3189/172756404781814375

Robin, G. d. Q. (1955). Ice movement and temperature distribution in glaciers and ice sheets. Journal of Glaciology, 2(18), 523-532. https:// doi.org/10.3189/002214355793702028

Schlosser, P., Bayer, R., Foldvik, A., Gammelsrød, T., Rohardt, G., \& Münnich, K. O. (1990). Oxygen 18 and helium as tracers of Ice Shelf Water and water/ice interaction in the Weddell Sea. Journal of Geophysical Research, 95(C3), 3253-3263.

Schröder, M. (2011). Hydrochemistry measured on water bottle samples during POLARSTERN cruise ANT-XII/3 [data set]. PANGAEA https://doi.org/10.1594/PANGAEA.756222

Slater, T., Shepherd, A., McMillan, M., Muir, A., Gilbert, L., Hogg, A. E., et al. (2018). A new digital elevation model of Antarctica derived from CryoSat-2 altimetry. The Cryosphere, 12(4), 1551-1562. https://doi.org/10.5194/tc-12-1551-2018

Toyota, T., Smith, I. J., Gough, A. J., Langhorne, P. J., Leonard, G. H., Van Hale, R. J., et al. (2013). Oxygen isotope fractionation during the freezing of sea water. Journal of glaciology, 59(216), 697-710. https://doi.org/10.3189/2013JoG12J163

Treasure, A. M., Roquet, F., Ansorge, I. J., Bester, M. N., Boehme, L., Bornemann, H., et al. (2017). Marine mammals exploring the oceans pole to pole: A review of the MEOP consortium. Oceanography, 30(2), 132-138. https://doi.org/10.5670/oceanog.2017.234

Vaughan, D. G, Comiso, J. C., Allison, I., Carrasco, J., Kaser, G., Kwok, R., et al. (2013). Observations: Cryosphere, Climate change 2013: The physical science basis. Contribution of working group $i$ to the fifth assessment report of the intergovernmental panel on climate change. Cambridge, United Kingdom and New York, NY, USA: Cambridge University Press.

Weiss, R., Östlund, H. G., \& Craig, H. (1979). Geochemical studies of the Weddell Sea. Deep Sea Research Part A. Oceanographic Research Papers, 26(10), 1093-1120. https://doi.org/10.1016/0198-0149(79)90059-1

Weppernig, R., Schlosser, P., Khatiwala, S., \& Fairbanks, R. (1996). Isotope data from ice station Weddell: Implications for deep water formation in the Weddell Sea. Journal of Geophysical Research, 101(C11), 25,723-25,739. https://doi.org/10.1029/96JC01895 